\title{
Polimer kotérhálók és kopolimerek: kaméleon gélektől intelligens gyógyszerhordozókig és nanokatalizátorokig*
}

\author{
IVÁN Béla** \\ Polimer Kémiai Kutatócsoport, Anyag-és Környezetkémiai Intézet, Természettudományi Kutatóközpont, \\ 1117 Budapest, Magyar tudósok krt. 2.
}

\section{Bevezetés}

100 évvel ezelőtt, 1920-ban egy napjainkig nagy jelentőséggel bíró közleményt jelentetett meg a polimerek (makromolekulák) koncepciójának megalkotásáért és ezzel kapcsolatos kutatómunkájáért az 1953-ban kémiai Nobel-díjjal elismert Herman Staudinger "Über Polymerisation" címmel a Berichte Der Deutschen Chemischen Gesellschaft címü folyóiratban ${ }^{1}$, melyben leírta a polimerek (makromolekulák) kis molekulatömegü molekulák (monomerek) összekapcsolódásával (polimerizációval) történő képződésének a menetét. Furcsa módon mind a makromolekulák létezésének, mind pedig ilyen módon lezajló képződésének a módját a kémikusok tág köre, köztük nem egy Nobel díjas, és a széles értelemben vett tudományos világ több mint egy évtizedig elutasította. ${ }^{2}$ Érdekes módon a vegyipar elöbb eszmélt, és az 1920-as évek végére már több, a fémekétől, fától és kerámiáktól eltérő tulajdonsággal rendelkező polimer gyártását kezdték meg. Ide tartoznak például a poliészterek és a poliamidok (nylon), amelyek már egyértelmúen polimer (makromolekula) megjelöléssel jelentek meg a szakirodalomban. ${ }^{3}$ Ezekből az új, korábban nem létező, a magyar szakirodalomban és köznyelvben "müanyag" megjelöléssel szereplő anyagokból napjainkban évente már több mint 370 millió tonnát állítanak elö és használnak fel világszerte. Ennek mennyisége a világgazdaság növekedését meghaladó ütemben folyamatosan növekszik, és várhatóan növekedni fog a jövőben is. Megjegyzendő, hogy helyesebb megkülönböztetni a polimerek (makromolekulák) elnevezést a "mủanyag" névtől, és mủanyagnak azokat az anyagokat tekinteni, amelyek polimerek feldolgozásával készülnek. Igy a továbbiakban ezt a két kifejezést ennek értelmében fogom használni.

Egy polimerekkel foglalkozó közleményben napjainkban nem kerülhető meg, nem kerülhető ki a műanyag termékekkel történő környezetszennyezés kérdése. A rendkívül nagy mennyiségben előállított és müanyagok előállítására felhasznált polimerek elhasználás után ugyanis hulladékként jelennek meg, és komoly gondot okoz ennek a hulladéknak a kezelése világszerte. Megjegyzendő, hogy a széles körben elterjedt nézet, miszerint a műanyagok szennyezik a környezetet annyiban hibás, miszerint nem maguk a mủanya- gok, hanem az emberek szennyezik a környezetet műanyagokkal (is). Magától értetődik, hogy az elhasznált műanyag termékek újrahasznosítása lenne környezetvédelmi szempontból a legjobb megoldás. Ez azonban még gyerekcipőben jár világszerte, nagyrészt gazdaságtalan volta miatt, továbbá amiatt, hogy a nagy mennyiségben alkalmazott polimerek többsége nem bomlik le a természetben még hosszú idő után sem. A müanyagok újrahasznosítási irányairól és a környezetszennyezés csökkentésének lehetőségeiről egy korábbi közleményben számoltam be. ${ }^{4}$ Meg szeretném jegyezni azt is, hogy a környezetszennyezés visszaszorítása, beleértve a műanyagokkal történő szennyezés megakadályozását, amellett, hogy igen jelentős kihívás a vegyészettel foglalkozók számára is, alapvetően össztársadalmi, azaz globális megoldásokat sürgető kérdés.

A 20. században tehát az emberiség történetében megjelent egy olyan új anyagfajta, a szintetikus polimerek, amelyek korábban nem léteztek, és a mai élet gyakorlatilag elképzelhetetlen ezen makromolekuláris anyagok nélkül. Nemcsak a mindennapi tárgyaink, hanem számos csúcstechnológiai termék, például a számítógépes chipek sem léteznének polimerek nélkül, amelyek gyártása a nagytisztaságú szilícium lapok mellett az úgynevezett fotoreziszt polimereken alapszik. Ugyancsak igen hasznos és fontos szerepet töltenek be az orvoslásban is a polimerekből készült gyógyászati termékek és eszközök, kezdve az eldobható injekciós fecskendőtől a gyógyszerkibocsátó szívkoszorúér sztent bevonatáig, implantátumokig, gyógyszerekig stb. Tekintettel arra, hogy az emberiség korszakait a számottevő szerepet játszó, egyes koronként megjelenő új, gazdaságilag, társadalmilag és az élet szempontjából jelentős anyagok szerint is csoportosítják, a kőkorszak, rézkorszak, bronzkorszak és vaskorszak után napjainkat egyre szélesebb körben polimer korszaknak nevezik. ${ }^{5,6}$ Kettős értelemben is beszélhetünk polimer korszakról, ugyanis a szintetikus polimerek térhódítása mellett igen jelentős fejlődés történt az úgynevezett biológiai makromolekulák terén is, mint például a poliszacharidok (cellulóz, keményítő stb.) és különösen a fehérjék (polipeptidek), valamint az örökítőanyag szerepét betöltő RNS és DNS esetében.

\footnotetext{
* A közlemény Iván Béla, az MTA rendes tagja 2020. február 18-án tartott akadémiai székfoglaló előadásának szerkesztett változata.

** Tel.: +36-1-382-6512; e-mail: ivan.bela@ttk.hu
} 
A szintetikus polimerek széleskörü gyártása és alkalmazása, beleértve az egyre bővülő és nagy hozzáadott értéket képviselö speciális alkalmazásokat is, minden kétséget kizáróan a polimer kémia terén és a hozzá kapcsolódó tudományterületeken bekövetkezett, napjainkban is zajló rendkívül intenzív alapkutatásnak és az ebből eredő nagyarányú fejlödésnek köszönhetö. Ide tartozik az is, hogy a polimer láncokat nemcsak egyféle, hanem kémiai szerkezetüket illetően többféle monomer egység építheti fel, és ebből eredően a kapott makromolekuláris anyagok tulajdonságai széles tartományban jól szabályozhatók. Másrészt pedig, amennyiben a polimerek megfelelő funkciós csoportokkal rendelkeznek, akkor lehetőség kínálkozik ezeket mintegy kiindulási anyagokként alkalmazni, amelynek révén eddig nem ismert új anyagok hozhatók létre. Ebben a közleményben az elmúlt fél évtizedben a kutatócsoportunkban ilyen irányokban folytatott kutatásaink néhány jellegzetes új eredményének az összegzésére kerül sor.

\section{2. Újszerű kopolimerek}

Az olyan polimereket, amelyekben nemcsak egyféle monomer egység fordul elő, kopolimereknek nevezzük. A polimer láncban random módon elhelyezkedő, különbözö kémiai szerkezetü monomer egységek, az úgynevezett random kopolimerek az egyik legszélesebb körben elterjedt, és igen nagy ipari jelentőségű osztályát képezik a kopolimereknek. Kutatásaink során megkíséreltünk olyan termikusan reszponzív (intelligens) kopolimereket előállítani, amelyek vizes oldatai nemcsak kritikus oldhatósági (szételegyedési) hőmérséklettel (CST = Critical Solution Temperature $)^{7}$, hanem szol-gél kémiai reakcióra alkalmas funkciós csoportokkal is rendelkeznek. A CST-vel rendelkező polimerek oldatainak ezen a hőmérsékleten megváltozik az oldhatósága, amely többek között abban is megnyilvánul, hogy az emiatt deszolvatálódott, vizes oldatban dehidratálódott polimerek aggregálódnak (kicsapódnak), és így az oldat átlátszatlanná válik. Ez azonban a termoreszponzív polimerek esetében egy megfordítható folyamat, és a hőmérséklet ellentétes irányú változásával a polimerek ismét feloldódnak. Meg kell itt jegyezzük, hogy a CST koncentrációtól való függése az ilyen polimerek esetében azok szerkezétől és az oldószerrel történő kölcsönhatásuk jellegétől függően vagy minimum vagy maximum görbét eredményez. Előbbit LCST-típusú (LCST = Lower Critical Solution Temperature), utóbbit pedig UCST-típusú (UCST = Upper Critical Solution Temperature) polimereknek nevezik. Azt is fontos megjegyeznünk, hogy a szakirodalomban igen nagyszámú olyan közlemény található, amelyben egy adott polimer koncentráció esetén mért CST értéket hibásan LCST, illetve USCT megnevezéssel adnak meg. Ezen túlmenően, mint azt egy nemrég címoldalra került közleményünkben ${ }^{7}$ szisztematikus kísérletekkel kimutattuk, a CST értéke nemcsak a polimer oldat koncentrációjától, hanem olyan kísérleti körülményektöl is függ, mint a hütés és fütés sebessége, valamint az oldat transzmittancia mérése esetében az átvilágítás fényének a hullámhossza. Szol-gél reakcióra alkalmas termoreszponzív polimerek kutatása során a bizonyos körülmények között testhömérséklethez közeli CST-vel rendelkező poli(N-izopropil-akrilamid)ot (PNIPAAm) választottuk kiindulópontnak, és vizsgáltuk a NIPAAm monomer 3-trimetoxiszililpropil-metakriláttal (TMSPMA) végmenő kopolimerizációját. ${ }^{8}$ Sikerült olyan gyökös kopolimerizációs körülményeket kidolgoznunk, amelyek az irodalmi példákkal ellentétben nem vezetnek gélesedéshez már a polimerizáció során. Ehhez nem az irodalomban széles körben használt, véleményünk szerint a gélesedést előidéző alkoholokat alkalmaztuk oldószerként, hanem 1,4-dioxánt. Ezt a kopolimerizációs folyamatot és az eredményeként kapott poli(N-izopropil-akrilamid-ko-3-trimetoxiszililpropil-metakrilát) (P(NIPAAm-ko-TMSPMA)) kopolimert mutatja az 1. ábra. Ezt az eljárást alkalmazva akár 10 mol\%-nál nagyobb TMSPMA tartalommal rendelkező gélmentes kopolimereket is sikerült előállítanunk. ${ }^{8}$

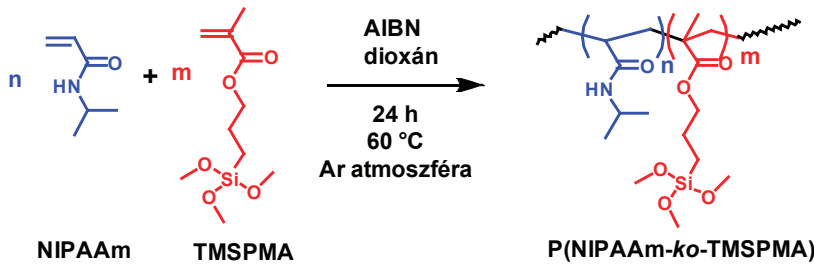

1. Ábra. A P(NIPAAm-ko-TMSPMA) kopolimer előállítása gyökös kopolimerizációval dioxán oldószerben.

Vizsgáltuk a P(NIPAAm-ko-TMSPMA) kopolimerek vizes oldatának termikus viselkedését, melynek során egy érdekes, eddig az irodalomban le nem írt jelenséget figyeltünk meg. Amint az a 2. ábrán látható, a szobahőfokon teljesen átlátszó PNIPAAm homopolimer vizes oldatának a transzmittanciája a hőmérséklet emelkedésével egy bizonyos ponton nullává válik, azaz az oldat átlátszatlan lesz, a polimer kicsapódik, oldhatatlan állapotba kerül. Ez egy megfordítható folyamat, azaz az oldat lehütésével visszaoldódik a polimer, az oldat újra átlátszó lesz, és ennek során hiszterézis figyelhető meg. ${ }^{7}$ Ezzel szemben a P(NIPAAm-ko-TMSPMA) kopolimer esetében azt a meglepő eredményt kaptuk, hogy amint azt a 3. ábra mutatja, már az első felmelegítés utáni lehütésre sem kapjuk vissza a kiindulási transzmittanciát, azaz a kopolimer nem oldódik fel teljesen a visszahütési folyamat során még hosszú idő után sem, vagy akár jelentős mértékű keverés alkalmazásával sem. ${ }^{8}$ Ezt azt jelenti, hogy a polimer láncok felfütéskor bekövetkező dehidratálása következtében kialakuló polimer aggregátumokban lejátszódik a térhálósodást eredményező szol-gél reakció anélkül, hogy ehhez bármilyen szokásos savas vagy bázikus jellegü katalizátort adnánk. A térhálósodás mértékére jellemző gélhányad a 3. ábrán mutatott első ciklus esetében 86\%-nak adódott, ami jelzi a nagyfokú térhálósodást a kicsapódott polimerben a CST feletti hömérséklet tartományban. Amint ezen az ábrán szintén látható, többszöri fütés-hütés ciklusra a hütés utáni transzmittancia tovább csökken. Ez az általunk felismert új térhálósodási folyamat számos eddig nem ismert termoreszponzív polimer gél létrehozására nyit új lehetőségeket. Meg szeretném jegyezni, hogy a P(NIPAAmko-TMSPMA) kopolimerek hagyományos szol-gél reakciójával kapott termoreszponzív hidrogélekkel kapcsolatban 
igazoltuk, hogy elnyújtott gyógyszerleadásra képes mátrixként alkalmazhatók mind az úgynevezett gélkollapszus hőmérséklete $(\mathrm{GCT}=\mathrm{Gel}$ Collapse Temperature) alatti, mind pedig a GCT feletti hőmérsékleteken is. ${ }^{9}$

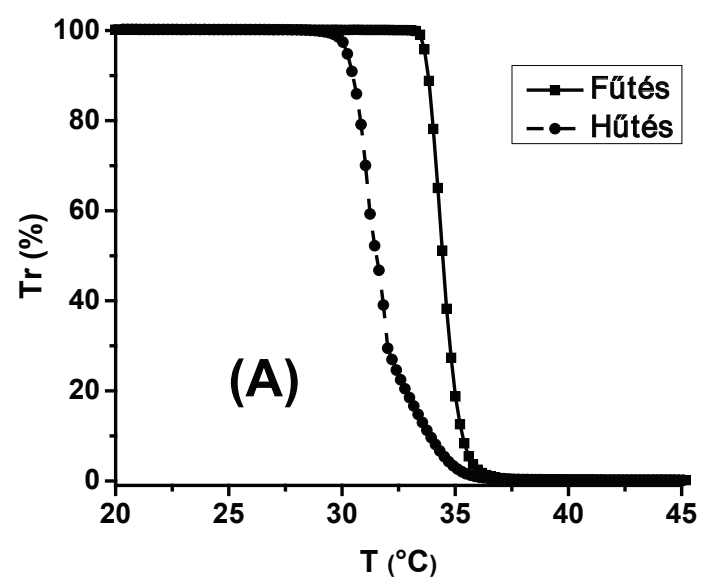

2. Ábra. A poli(N-izopropil-akrilamid) $1 \mathrm{mg} / \mathrm{mL}$ koncentrációjú vizes oldatának transzmittanciája felfütés és azt követő lehűtés során (fütési/ hủtési sebesség: $0,2^{\circ} \mathrm{C} / \mathrm{min} 5$ perces várakozási időkkel, $488 \mathrm{~nm}$ ).

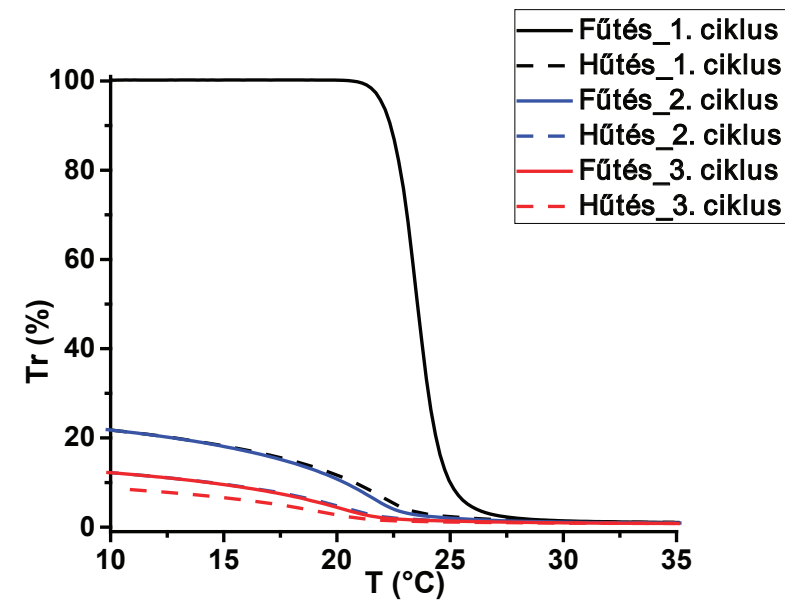

3. Ábra. A 11,1 mol\% TMSPMA tartalmú P(NIPAAm-ko-TMSPMA) kopolimer vizes oldatának a transzmittanciája a hőmérséklet függvényében három fütési-hütési ciklusban (a folytonos vonal a felfütést, a szaggatott vonal a lehütést jelzi; fütési/hütési sebesség: $0,2{ }^{\circ} \mathrm{C} / \mathrm{min} 5$ perces várakozási időkkel, koncentráció: $1 \mathrm{mg} / \mathrm{mL}, 488 \mathrm{~nm}$ ).

Abban az esetben, ha olyan kopolimereket hozunk létre, amelyekben homopolimer láncok kapcsolódnak egymáshoz, blokk-kopolimerekhez jutunk. Kutatásaink során sikeresen elöállítottunk kovalens kötéssel egymáshoz kapcsolt hiperelágazásos poliglicerol (HbPG) és poli(tetrahidrofurán) (PTHF) láncokból álló olyan ABA típusú blokk-kopolimereket, amelyekben két HbPG molekulát egy központi PTHF lánc kapcsol össze (HbPG-PTHF-HbPG). Ennek a sematikus szerkezetét mutatja a 4. ábra. A HbPG-PTHFHbPG blokk-kopolimer szintéziséhez amino-telekelikus PTHF-et, mint a glicidol gyürüfelnyílásos multielágazásos polimerizációja (ROMBP = Ring-Opening Multibranching
Polymerization) makroiniciátoraként alkalmaztuk. Ez a folyamat látható az 5. ábrán, mellyel többféle összetételben sikerült előállítani HbPG-PTHF-HbPG blokk-kopolimereket. ${ }^{10} \mathrm{Az}$ irodalomban eddig mindössze egy közleményt ${ }^{11}$ találni, amely ennek a blokk-kopolimernek az előállításával foglalkozik hidroxi-telekelikus PTHF makroiniciátorként történő alkalmazásával. A közölt eredmények azonban kérdésessé teszik ennek a sikerességét. Ezzel szemben az általunk alkalmazott amino-telekelikus makroiniciátorral nagy hatékonysággal sikerült előállítani különböző összetételü HbPG-PTHF-HbPG triblokk-kopolimereket.

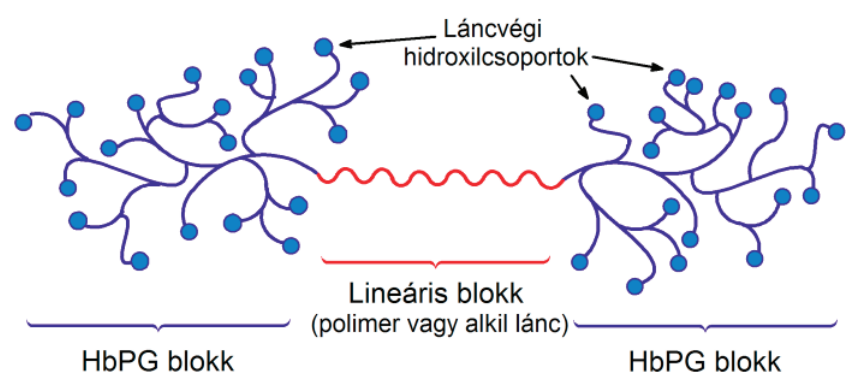

4. Ábra. A HbPG külső blokkokkal rendelkező ABA blokk-kopolimerek sematikus szerkezeti felépítése.

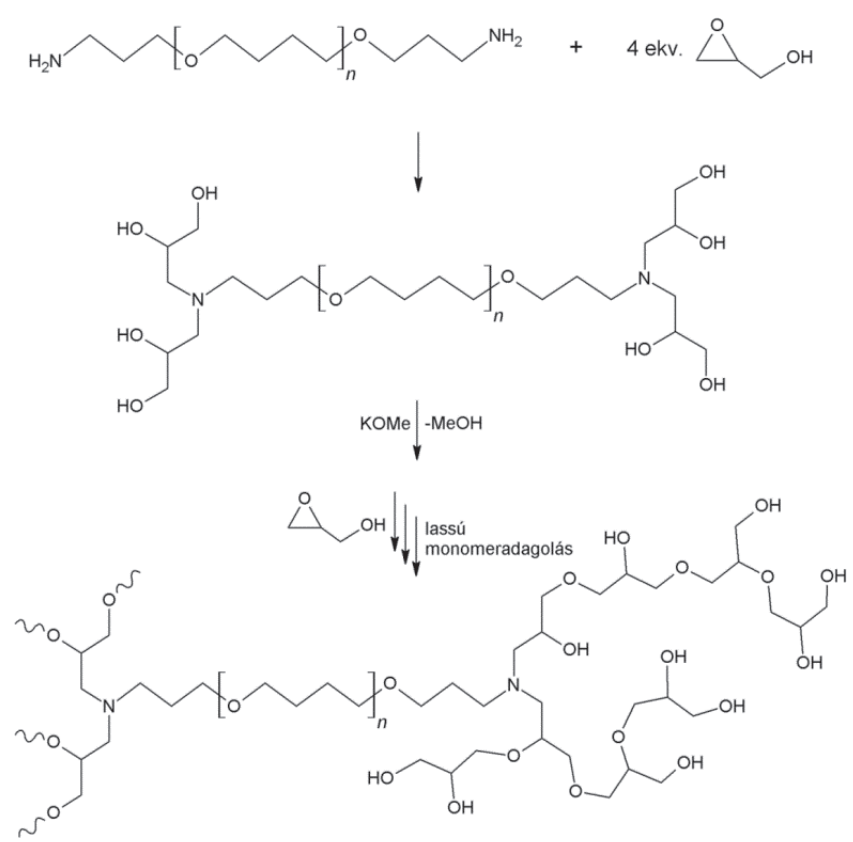

5. Ábra. HbPG-PTHF-HbPG ABA triblokk-kopolimer előállítása glicidol anionos gyürűfelnyílásos multielágazásos polimerizációjával amino-telekelikus poli(tetrahidrofurán) makroiniciátor alkalmazásával.

A hiperelágazásos poliglicerolról (HbPG) meg kell jegyezzük, hogy világszerte igen intenzív kutatások folynak ezzel a random elágazásokat tartalmazó polimerrel, tekintettel arra, hogy egy biokompatibilis, széles körben engedélyezett élelmiszeradalék, és gyógyászati alkalmazásokban kiválthatja a hosszú távon a szervezetben felhalmozódó poli(etilén-glikol)t (PEG) és származékait. A megcélzott HbPGPTHF-HbPG másik összetevője, a PTHF és elsősorban az ebből készült olyan polimerek, mint a poliuretánok rég- 
óta ismert és gyógyászatban alkalmazott biokompatibilis anyagok. A két polimer összekapcsolásával, melyek közül a HbPG vízoldható hidrofil, míg a PTHF apoláris szerves oldószerekben oldódó hidrofób makromolekula, egy amfifil karakterü, önszerveződésre képes, biokompatibilis ABA blokk-kopolimer előállítását céloztuk meg. Az általunk előállított HbPG-PTHF-HbPG blokk-kopolimerek amfifil jellegét igazolja, hogy vizes oldataik $10^{-4} \mathrm{~mol} / \mathrm{L}$ körüli kritikus micellaképződési koncentrációval rendelkeznek, és a cmc-nél nagyobb polimer koncentrációk esetén belölük 10-15 nm átmérőjű micellák képződnek.

Közismert, hogy számos olyan hatóanyag létezik, amelyek gyógyászati alkalmazásának egyik jelentős akadályozó tényezője azok igen alacsony vízoldhatósága. Ilyen például a kurkumin (6. ábra), amely egy természetes daganatellenes szerként nyilvántartott vegyület, és vízoldhatósága mindössze $2,98 \cdot 10^{-6} \mathrm{~mol} / \mathrm{L}$. Szisztematikus kísérleteket folytattunk a kurkumin vízoldhatóságát illetően a vizes oldatban micellákat képező HbPG-PTHF-HbPG blokk-kopolimerek jelenlétében. Azt találtuk, hogy a cmc fölötti tartományban a HbPG-PTHF-HbPG koncentrációjának növelésével rendkívüli mértékben megnő a kurkumin oldhatósága, vagyis a HbPG-PTHF-HbPG mintegy molekuláris kapszulázószerként viselkedik. A 7. ábrán a kurkumin micella-víz partíciós koefficiense látható a polimer koncentráció függvényében. Amint az erről az ábráról kitünik, a HbPGPTHF-HbPG több mint 700-szorosára képes növelni a kurkumin vízoldhatóságát. Fontos megjegyezni, hogy mind a HbPG-PTHF-HbPG micellák, mind pedig a kapszulázott kurkumin tartalmú micellák nagy stabilitással rendelkeznek. NMR vizsgálatok azt mutatják, hogy a hatóanyag a micellák hidrofób összetevőjében, azaz a PTHF fázisban található a micellákban. Ezen túlmenően a liofilizált anyagok újraoldhatóak és megtartják alapvető tulajdonságaikat. Mint azt a 8. ábra mutatja, a HbPG-PTHF-HbPG nanomicellákba kapszulázott kurkumin elnyújtott idejü hatóanyag leadást biztosító gyógyszerhordozó. Citotoxikussági vizsgálatokkal azt találtuk, hogy a HbPG-PTHF-HbPG még viszonylag nagy koncentrációkban és hosszas kezelés esetén sem mutat citotoxicitást. Ezen felül a U-87 glioblastoma sejtekkel végzett kísérletek arra az eredményre vezettek, hogy a szabad kurkuminhoz képest minden kurkuminnal töltött polimer micella esetén nőtt a sejtbejutás. ${ }^{10}$<smiles>COc1cc(/C=C/C(=O)CC(=O)/C=C/c2ccc(O)c(OC)c2)ccc1O</smiles>

6. Ábra. A kurkumin.

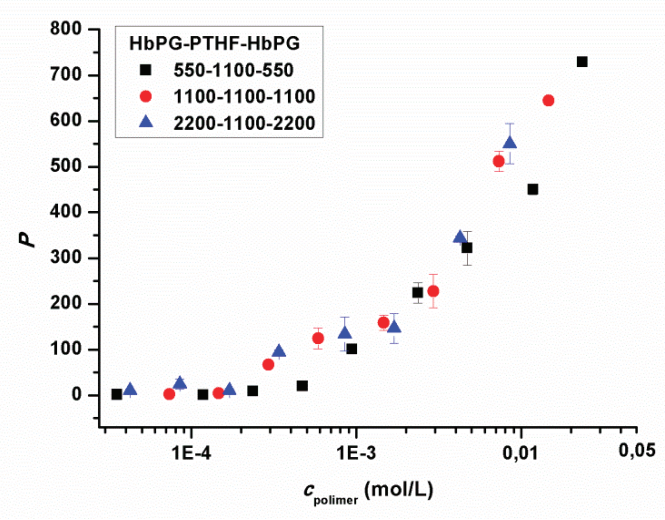

7. Ábra. A micella-víz partíciós koefficiense a HbPG-PTHF-HbPG amfifil triblokk-kopolimerek koncentrációjának a függvényében.

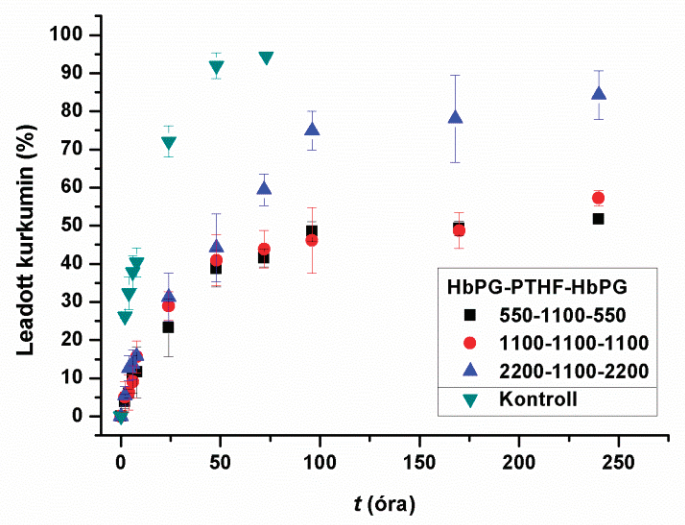

8. Ábra. A HbPG-PTHF-HbPG blokk-kopolimerek által képződött micellákból leadott kurkumin relatív mennyisége az idő függvényében.

Ezeken az eredményeken túlmenően igen ígéretesnek tünnek azok az eredményeink is, amelyek arra vezettek, hogy a glicerol gyürüfelnyílásos multielágazásos polimerizációját 1-oktadekanollal iniciálva olyan $\mathrm{HbPG}$ alapú $\mathrm{AB}$ blokk-kopolimerhez jutunk, amely egy oktadecil csoportot, azaz egy rövid polietilén szegmenst tartalmaz makromolekulánként (C18-HbPG). ${ }^{12}$ Ez az amfifil karakterü polimer igen hatékonynak bizonyult vizes közegben mind poli(glikolsav-ko-tejsav) kopolimerek (PLGA), mind pedig poli( $\varepsilon$-kaprolakton) (PCL) nanorészecskék stabilizálására. ${ }^{12,13}$ Ezek a C18-HbPG-vel stabilizált biokompatibilis és biodegradábilis polimerek ígéretes nanohordozónak bizonyultak a kurkumin esetében. Azt találtuk, hogy a PCL-kurkumin kölcsönhatás erösebb a PLGA-kurkumin eseténél. A 10 w/w\% kurkumint tartalmazó, C18-HbPG-vel stabilizált PCL kurkumin leadásával kapcsolatos vizsgálatok azt mutatták, hogy erösen pH-függő a kurkumin leadása, kismértékü 7-es pH alatt, míg elnyújtott leadás tapasztalható a bélrendszer $\mathrm{pH}$-ját szimuláló oldatban $(\mathrm{pH}=7,4)$, ahol $\sim 80 \%$ kurkumin leadás történik 8-12 óra alatt. ${ }^{13}$ Ezeknek az új eredményeknek az alapján többféle HbPG-t tartalmazó amfifil AB blokk-kopolimerrel stabilizált gyógyszerhordozó nanorészecske létrehozása képzelhető el, elsősorban biológiailag lebomló polimerekből létrehozott nanorészecskék stabilizálása révén. 
Nemrég sikerült a glicidol olyan polimerizációját kidolgoznunk, amely makromolekulánként egy amino csoportot tartamazó HbPG-t eredményezett. ${ }^{14}$ Ezt a glicidol gyürüfelnyílásos elágazásos polimerizációjának ftálimid-káliummal történő iniciálásával értük el, amelynek során ftálimidet tartalmazó makromolekulához jutottunk (9. ábra). Az így kapott HbPG-t hidrazin-monohidráttal reagáltatva olyan HbPG-t kapunk, amely egy amin-csoportot tartalmaz. Az amin-csoport további lehetőségeket kínál újabb funkciós csoportok kialakítására, mint az a 10. ábrán látható, mely karboxil, maleimid és klóracetamid csoportok képződését mutatja. A monoamino-funkciós HbPG, tekintettel a HbPG fentebb már említett biokompatibilitására és a PEG-gel szembeni előnyére, alkalmas polipeptidek konjugálására. Különösen fontos ez olyan esetekben, amikor receptor-specifikus peptid révén kívánnak hatóanyagot bejuttatni szelektíven rákos sejtekbe. Ilyen esetekben ugyanis a gyógyszer-peptid konjugátum többnyire hidrofób karakterü, és nem oldódik megfelelő mértékben vízben. Megkíséreltünk létrehozni egy olyan gyógyszer-peptid-HbPG konjugátumot, amelyet a hozzákapcsolt HbPG vízoldhatóvá tesz, és alkalmas sejtspecifikus gyógyszerhordozónak. ${ }^{15}$ Ennek során daganatos megbetegedések terápiájában alkalmazott daunomycin kapcsolására került sor egy katepszin B enzimmel könnyen hasítható peptid közbeiktatásával epidermális növekedési faktor receptorhoz (EGFR) kapcsolódó peptidhez, amely a vízoldhatóságot biztosító amin-funkciós PEG-hez, illetve HbPG-hez van kovalens kötéssel rögzítve. Az így felépülő blokkokból álló konjugátumok vizsgálata során kiderült, hogy a konjugátumok alkotóelemeinek megfelelő megválasztásával, elsősorban rövid receptor-specifikus peptidek esetében a HbPG-peptid blokk-kopolimerek (konjugátumok) kiemelkedően jó receptor kötődési és sejtfelvételi tulajdonságokkal rendelkeznek. ${ }^{15}$ Ezek az új eredmények egyúttal arra is utalnak, hogy a HbPG-n alapuló biokonjugátumok ígéretes lehetőségeket kínálnak a sejtspecifikus, különösen a daganatos sejteket célzó terápiákban.

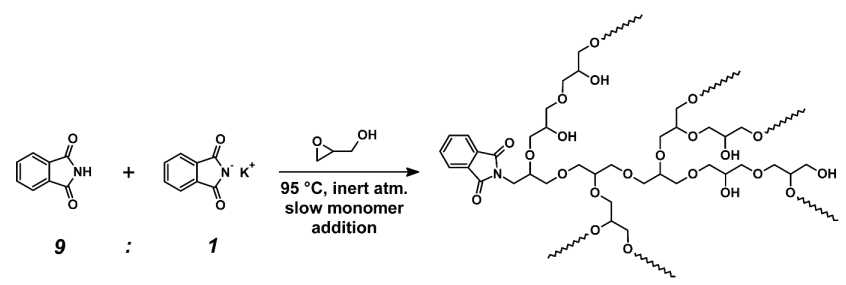

9. Ábra. Makromolekulánként egy ftálimid csoportot tartalmazó hiperelágazásos poliglicidol szintézise glicidol ftálimid/ftálimid-kálium eleggyel iniciált gyűrűfelnyílásos multielágazásos polimerizációjával.

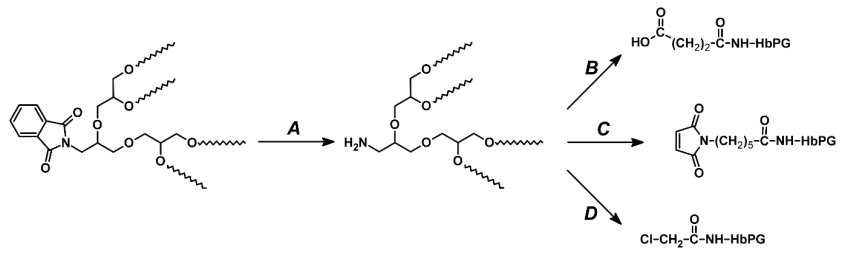

10. Ábra. A mono-ftálimid csoport átalakítása amin csoporttá, majd karboxil, maleimid és klóracetamid csoport kialakítása hiperelágazásos poliglcidol láncon (A: hidrazin-monohidrát, B: borostyánkősav anhidrid, C: 6-maleimid-hexánsav, D: pentaklórfenil-klóracetát)

\section{Polimer kotérhálók}

Kutatócsoportunkban hosszabb ideje foglalkozunk olyan térhálós polimerekkel, amelyekben a térhálósítószer nem kis molekulatömegü kettő vagy több funkciós csoporttal rendelkező molekula (térhálósítószer), hanem megfelelő funkciós csoportokkal rendelkező makromolekula. Az ilyen térhálókat, amelyekben az egyik polimer lánc a térhálósító szere a másik polimer láncnak, kotérhálóknak nevezzük. Különösen nagy érdeklödés kíséri világszerte az amfifil kotérhálók (AKTH-k) kutatását, amelyek egymással nem elegyedő, kovalens kötéssel összekapcsolt hidrofil és hidrofób láncokból épülnek fel. Ezt a széleskörü érdeklődést tükrözi, hogy a Royal Society nemrég adott ki egy ezekkel az anyagokkal foglalkozó könyvet, ${ }^{16}$ amelyben az egyik fejezet kutatócsoportunk N-vinil-imidazolon alapuló amfifil kotérhálókkal eddig elért eredményeinek az összegzéséről szól. ${ }^{17}$

A polimer kotérhálók egyik leggyakoribb előállítási eljárása az úgynevezett makromonomer módszer, amelynek során egy polimerizációra képes végcsoportokkal rendelkező, azaz telekelikus polimert kopolimerizálnak egy kis molekulatömegű monomerrel, többnyire gyökös kopolimerizációval. Ezt a folyamatot mutatja a poli(N-vinil-imidazol)-l-poli(tetrahidrofurán) (PVIm-l-PTHF) szintézisére a 11. ábra, melynek során metakrilát-telekelikus PTHF és VIm kopolimerizációja eredményezi ezt a különleges anyagot. (A kotérhálók elnevezésében az -l- rövidítés a "linked by" kifejezést jelöli.) Ahhoz hogy egy ilyen folyamat révén a megcélzott kotérháló képződjön, valamint ne lépjen fel fázisszétválás a szintézis során, több követelménynek kell egyidejűleg teljesülnie: (1) a monomer és makromonomer kopolimerizálható legyen, azaz a makromonomer polimerizálható csoportjai és a kopolimerizációban résztvevő kis molekulatömegű monomer szerkezete olyan legyen, hogy ezek hatékonyan részt tudjanak venni a kopolimerizációs reakcióban, azaz az egymás iránti reaktivitásuk megfelelő legyen; (2) olyan polimerizációs körülményeket kell teremteni, hogy a térhálós polimer létrejöttéhez legalább kettő makromonomer beépüljön a kis molekulájú monomer mindegyik növekvő láncába, amit gyökös koplimerizációban a monomerek és az iniciátor koncentrációja arányának helyes megválasztásával lehet elérni; (3) olyan közös oldószerben vagy oldószer elegyben kell kivitelezni a polimerizációt, amelyben az összes komponens, azaz a telekelikus makromonomer, a kis molekulájú monomer és a belőle képződő polimer is oldódik, máskülönben a polimerizáció során fázisszeparáció lép fel, és nem képződik kotérháló.
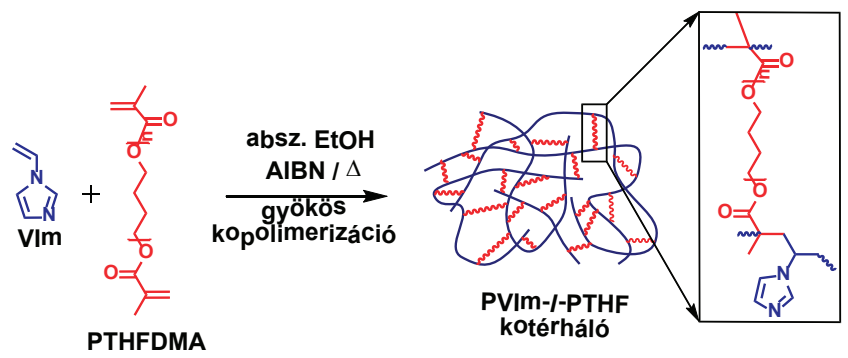

11. Ábra. A poli(N-vinil-imidazol)-l-poli(tetrahidrofurán) (PVIm-l-PTHF) amfifil kotérháló makromonomer módszerrel történő előállításának a sémája.

127. évfolyam, 1. szám, 2021. 
Az N-vinil-imidazol alapú kotérhálók több szempontból is kitüntetett helyet foglalnak el a kotérhálók között. Az imidazol gyürü egyrészt megtalálható a legfontosabb biomakromolekulákban (DNS, RNS, fehérjék), enzimekben, B-12 vitaminban, számos gyógyszerben és növényvédőszerben, ionos folyadékokban stb. Másrészt pedig az imidazol, szerkezetéből következően számos fémionnal képes stabil komplexeket képezni. A 11. ábrán feltüntetett szerkezetü kotérhálót két olyan polimer alkotja, amelynek homopolimerjei, azaz a poli(N-vinil-imidazol) (PVIm) és a poli(tetrahidrofurán) (PTHF) nem elegyednek egymással. A köztük lévő erős kémiai kötés azonban meggátolja a makroszkópikus szételegyedésüket a kotérhálókban. Az egymással nem elegyedő polimer láncokból felépülő kotérhálók esetében kezdetektől fogva az egyik legalapvetőbb kérdésként merült fel az, hogy ezek miként helyezkednek el a kotérhálókban. Ennek felderítésére általunk korábban kidolgozott ${ }^{18}$ reakciókörülményeket alkalmazva szisztematikus kísérletsorozattal különböző átlag molekulatömegü PTHF makromonomerekkel széles összetétel tartományban előállítottunk egy PVIm-l-PTHF amfifil kotérháló mintasorozatot, és alapvető tulajdonságaik felderítése mellett atomerő mikroszkópiával (AFM) vizsgáltuk a kotérhálók összetételtől és a PTHF keresztkötő átlag molekulatömegétől függő morfológiáját. ${ }^{19}$ Különböző hidrofil (víz, metanol) és hidrofób ( $\mathrm{THF}, \mathrm{CCl}_{4}$ ) oldószerekben történő duzzadás során kapott egyensúlyi duzzadási fok értékeket mutatja a 12. ábra a kotérhálók PTHF tartalmának a függvényében. Jól kitűnik erről az ábráról, hogy a kotérhálók amfifil tulajdonságúak, azaz az összetételtől függő mértékben képesek mind hidrofil, mind pedig hidrofób oldószerekben duzzadni, vagyis mindegyik típusú anyaggal kölcsönhatásba lépni. Ezt azt jelenti, hogy ezek a kotérhálók a környezetüktől (oldószertől) függően vagy hidrogélként vagy organogélként (hidrofób gélként) viselkednek. Az ilyen típusú anyagokat, azaz amelyek a környezetüktől függően képesek más-más tulajdonságot mutatni, "kaméleon" anyagoknak nevezik. A kotérhálók ilyen típusú viselkedését többféle alkalmazásban is fel lehet használni, mint arra majd példa is szerepelni fog a továbbiakban.

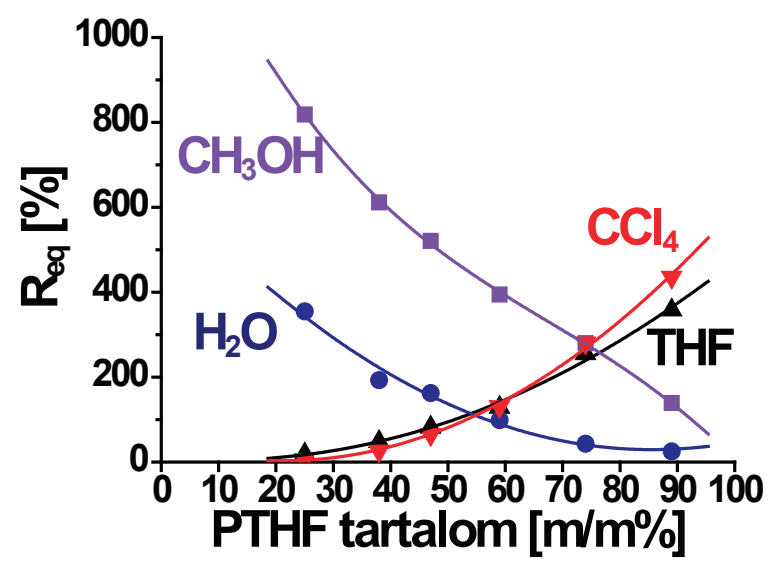

12. Ábra. A poli(N-vinil-imidazol)-l-poli(tetrahidrofurán) (PVIm-l-PTHF) kotérhálók egyensúlyi duzzadási foka $\left(\mathrm{R}_{\mathrm{eq}}\right)$ különböző oldószerekben a kotérhálók PTHF tartalma függvényében $\left(\mathrm{M}_{\mathrm{n}, \mathrm{PTHF}}=2170 \mathrm{~g} / \mathrm{mol}\right)$.
A kotérhálókkal, különösen az amfifil kotérhálókal kapcsolatos kutatások kezdetétől alapvető kérdésként merül fel, hogy az egymással makroszkópikusan nem elegyedő polimer láncok milyen térbeli elrendeződésben találhatók ezekben a különleges anyagokban. Ennek tisztázása érdekében kutatócsoportunkban előállítottunk széles összetétel tartományban különböző átlag molekulatömeggel rendelkező MA-PTHF-MA makromonomerekkel PVIm-l-PTHF kotérhálókat, és a Freburgi Egyetem munkatársaival együttmüködve atomerő mikroszkópiás (AFM) vizsgálatokkal felderítettük ezeknek az anyagoknak a morfológiáját. ${ }^{19,20}$ Ennek során azt találtuk, hogy ezekben az anyagokban az egymással kovalens kötéssel összekapcsolt, egymással nem elegyedő polimer komponensek nanométer tartományba eső, rendezetlen elrendezésben elkülönülö doméneket alkotnak. Kisebb térhálósító arányoknál a térhálósító komponens elkülönülten a másik komponens, a PVIm- $l$-PTHF esetében a PVIm fázisba ágyazódóan foglal helyet irreguláris szférikus domén szigetekként. A PTHF mennyiségét növelve széles összetétel tartományban ( 40-65 w/w\%) kölcsönösen folytonos (kofolytonos), azaz egymásba fonódó nanofázisok vannak jelen ezekben a kotérhálókban, amely többféle alkalmazási lehetőséget is előrevetít. Egy ilyen kölcsönösen folytonos nanofázisú morfológiával rendelkező PVIm- $l$-PTHF kotérháló fázismódusú AFM képét mutatja a 13. ábra. Nagyobb keresztkötő arányoknál a másik összetevő, azaz a PVIm jelenik meg elkülönült nanoméretü egyedi fázisokként. Amint a 14. ábrán látható, a PTHF keresztkötő mennyiségének, azaz a térhálósűrűségnek a növelésével a doménméretek csökkennek, és az összetételtől függően az elkülönülő komponensek átlagos doménmérete az 5-15 nm, míg az átlagos doméntávolság a 10-30 nm tartományba esik. Ezt kisszögü röntgenszórási (SAXS) vizsgálatok is alátámasztották. ${ }^{20}$ Ha összevetjük az AFM vizsgálatokkal nyert eredményeket a 12. ábrán látható duzzadási vizsgálatok eredményeivel, akkor megállapíthatjuk, hogy a mind hidrofil, mind pedig hidrofób oldószerekben duzzadni képes kotérhálók összetételi tartománya ( 40-65 w/w\%) igen jó egyezést mutat az AFM mérésekkel kapott kofolytonos morfológiájú elrendezést mutató kotérháló öszszetétellel. Ez azt jelenti, hogy a kölcsönösen folytonos (kofolytonos) nanofázisú szerkezet biztosítja a mindkét típusú oldószerben lehetséges duzzadási képességet ezekben az amfifil kotérhálókban. Meg kell jegyezzük, hogy a PVIml-PTHF kotérhálók rendezetlen nanofázisú morfológiájára kapott eredmények jól egyeznek korábbi, poli(2-hidroxietil-metakrilát)- $l$-poliizobutilén kotérhálók esetén kapott eredményekkel. ${ }^{21}$ 


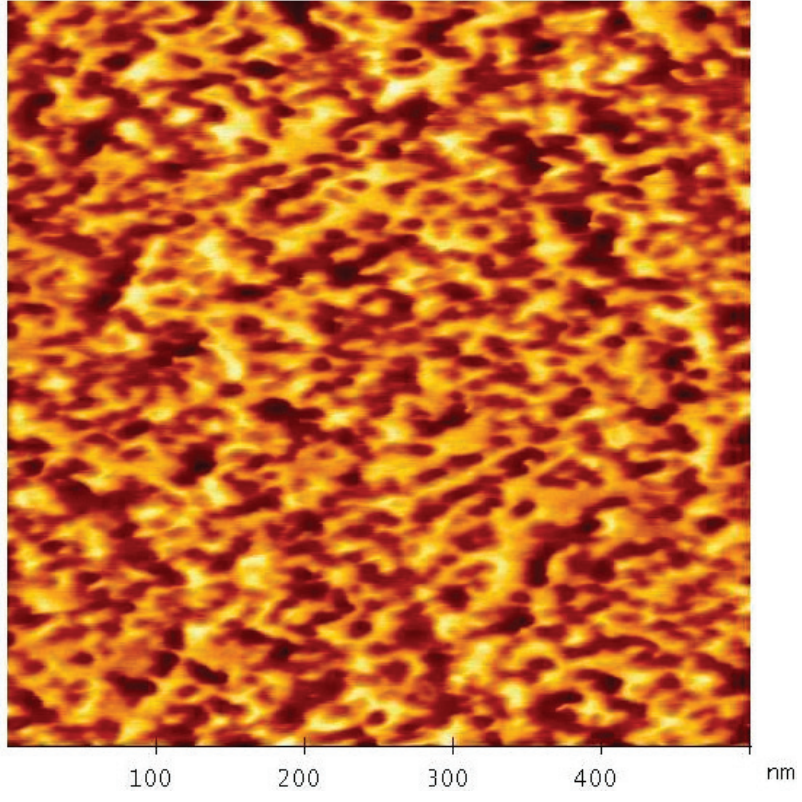

13. Ábra. Egy kölcsönösen folytonos nanofázis szeparált morfológiával rendelkezö poli(N-vinil-imidazol)-l-poli(tetrahidrofurán) (PVIm-l-PTHF) kotérháló minta fázis módusú AFM felvétele, melyben a sötét részek a PTHF, a világos részek a PVIm fázisokat jelzik $\left(\mathrm{M}_{\mathrm{n}, \mathrm{PTHF}}=2170 \mathrm{~g} / \mathrm{mol}, 47 \mathrm{w} \%\right.$ PTHF tartalom, kép mérete: 500x500 nm).

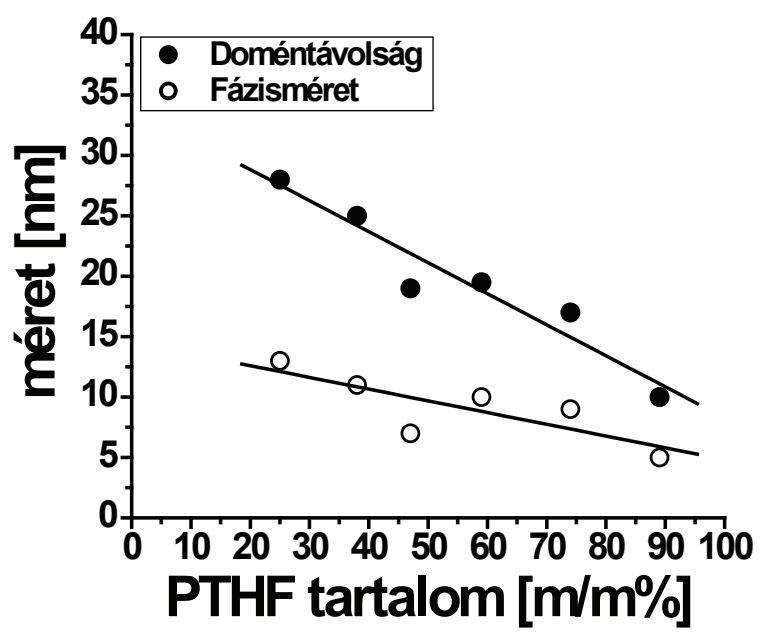

14. Ábra. Az AFM mérésekkel a poli(N-vinil-imidazol)-l-poli(tetrahidrofurán) (PVIm-l-PTHF) kotérhálókban a PTHF fázisokra kapott átlagos doménméret és a fázisok átlagos doméntávolsága a PTHF tartalom függvényében $\left(\mathrm{M}_{\mathrm{n}, \mathrm{PTHF}}=2170 \mathrm{~g} / \mathrm{mol}\right)$.

Differenciális pásztázó kalorimetriával (DSC) történt vizsgálatok során azt találtuk, hogy az eddig vizsgált fázisszeparációt mutató kotérhálók két üvegesedési hőmérséklettel $\left(\mathrm{T}_{\mathrm{g}}\right)$ rendelkeznek. Ez, egyezésben az AFM-mel végzett vizsgálatok eredményeivel, szintén igazolja az amfifil kotérhálók fázisszeparált szerkezetét. ${ }^{19-22}$ Korábbi vizsgálataink során arra a meglepő eredményre jutottunk, hogy a PVIm-l-PTHF kotérhálók esetében a PVIm komponens $\mathrm{T}_{\mathrm{g}}$-je csökken a PTHF keresztkötő relatív mennyiségének, azaz a térhálósürüség növekedésével, és ezzel együtt a PVIm keresztkötések közötti átlagos molekulatömegének $\left(\mathrm{M}_{\mathrm{c}}\right)$ a csökkenésével. ${ }^{22}$ Még meglepőbb eredményt kaptunk, ha a kapott $\mathrm{T}_{\mathrm{g}}$ értékeket ábrázoltuk a homopolimerekre ismert Fox-Flory összefüggés szerint $\left(T_{g}=T_{g, \infty}-K /\right.$ $\mathrm{M}_{\mathrm{n}}$, ahol $\mathrm{T}_{\mathrm{g}, \infty}$, a végtelen hosszú homopolimer üvegesedési hőmérséklete, $\mathrm{K}$ anyagi állandó, $\mathrm{M}_{\mathrm{n}}$ pedig a homopolimer számátlag molekulatömege), azaz a PVIm komponens $\mathrm{T}_{\mathrm{g}}$ jét az $1 / \mathrm{M}_{\mathrm{c}}$ függvényében, ugyanis függetlenül a PTHF keresztkötő átlagos molekulatömegétől ez az ábrázolás egyenest eredményezett. Ez azt jelenti, hogy a PTHF keresztkötő úgy viselkedik a kotérhálókban mint egy "molekuláris olló", és mintegy elvágva a PVIm láncokat, azok az üvegesedési átmenet szempontjából úgy viselkednek, mint a megfelelő hosszúságú szabad homopolimer láncok. Ezt az általunk elsőként felismert jelenséget "olló effektus" megjelöléssel neveztük el. Magától értetődő kérdésként merült fel, hogy vajon ez a PVIm-l-PTHF kotérhálókra jellemző egyedi jelenség, vagy érvényes-e más kotérhálók esetében is. Ennek felderítése érdekében szisztematikus kísérleti munkával elöállítottunk összetétel és ezzel együtt $M_{c}$ szempontjából is jól definiált poli(metil-metakrilát)-l-poliizobutilén (PMMA-l-PIB) kotérháló sorozatot öt különböző molekulatömegü metakrilát-telekelikus poliizobutilén (MA-PIB-MA) és metil-metakrilát (MMA) kopolimerizációjával, majd DSC mérésekkel meghatároztuk a komponensek $\mathrm{T}_{\mathrm{g}}$ értékeit. ${ }^{23}$ Mint a 15 . ábrán láthatjuk, a PMMA $\mathrm{T}_{\mathrm{g}}$ értékei a kotérhálókban az $1 / \mathrm{M}_{\mathrm{c}}$ függvényében ebben $\mathrm{az}$ esetben is egy egyenesre esnek. Az így kapott egyenes meredekségéből kapott $\mathrm{K}$ értékre $4.83 \cdot 10^{4}{ }^{\circ} \mathrm{Cg} / \mathrm{mol}$ adódott, ami igen jó egyezésben van az irodalomban a PMMA homopolimerekre kapott K értékkel $\left(4.67 \cdot 10^{4}{ }^{\circ} \mathrm{Cg} / \mathrm{mol}\right) .{ }^{24}$ Ezek az eredmények tehát azt jelentik, hogy újabb példa igazolja az olló effektust a makromolekuláris keresztkötővel kapott, egymással nem elegyedő polimer komponensekből álló kotérhálók esetében. Mindez azt jelenti, hogy joggal feltételezhetjük, miszerint ez egy általános jelenség lehet az ilyen típusú kotérhálók esetében. Erre utalnak jelenleg más öszszetevőkből álló kotérhálókkal folyamatban lévő vizsgálataink eddigi eredményei is. Mivel a felhasználás szempontjából döntő jelentőséggel bír egy makromolekuláris anyag $\mathrm{T}_{\mathrm{g}}$-je, ezeknek az eredményeknek az ismeretében ebből a szempontból jól tervezhetővé válnak a polimer kotérhálók.

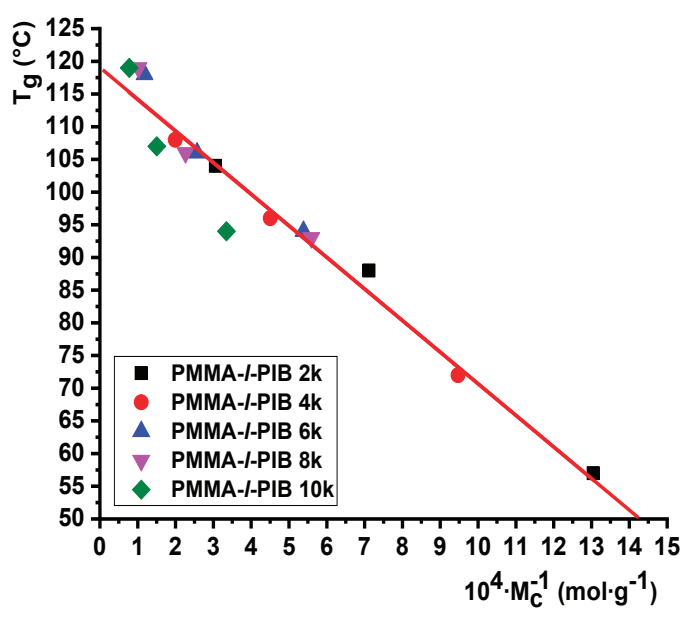

15. Ábra. A poli(metil-metakrilát (PMMA) komponens üvegesedési hőmérséklete $\left(\mathrm{T}_{\mathrm{g}}\right)$ a poli(metil-metakrilát)-l-poliizobutilén (PMMA-l-PIB) kotérhálókban az $1 / M_{c}$ függvényében. 
Mint ismeretes, az ionos folyadékok igen széles körü érdeklődést váltottak ki. Napjainkban pedig az olyan polimerek kutatása is elötérbe került, amelyek ionos folyadék tulajdonságú csoportokat tartalmaznak. Ezeket a polimereket poli(ionos folyadék)oknak $\left(\mathrm{PIL}=\right.$ poly(ionic liquid)) hívják. ${ }^{20}$ Tekintettel arra, hogy a legtöbb ionos folyadék alkilezett imidazolon alapszik, megkíséreltünk létrehozni egy eddig a szakirodalomban tudomásunk szerint egyáltalán nem szereplő új anyagot, amely poli(N-vinil-imidazol) alapú kotérháló alkilezésével olyan PIL kotérhálót (PIL-CN = poly(ionic liquid) conetwork) eredményez, amelyben a fentiekben bemutatott nanoszerkezetü elrendezésben foglal helyet az imidazol gyürük alkilezésével nyert PIL komponens. Ezt úgy értük el, hogy a nanofázisú PVIm-l-PTHF kotérhálókat metil-jodiddal kezeltük. ${ }^{20}$ Ezt a folyamatot mutatja a 16. ábra. Azt találtuk, hogy ez az eljárás nagyfokú alkilezést eredményez, és a létrejövő PIL-CN-ek megtartják a nanofázisszeparált szerkezetet, mint azt az AFM és SAXS mérések eredményei mutatják. Jól tükrözi a PIL-CN-ek nanofázisú szerkezetét az is, hogy a SAXS görbéken (17. ábra) a szórási maximum helye, azaz az átlagos doméntávolság csak kismértékben változik a metilezés hatására. A kapott nanofázisú PIL-CN-ek duzzadási viselkedését összehasonlítottuk a PVIm-l-PTHF kotérhálók duzzadási képességével, és nemvárt eredményeket kaptunk. A PIL-CN-ek egyensúlyi duzzadási foka ugyanis több poláros oldószerben is, például víz, alkoholok, acetonitril, kisebbnek adódott, mint a kiindulási kotérhálóké, ugyanakkor olyan aprotikus poláros oldószerek esetében, mint a DMSO, DMF és N-metil-pirrolidon (NMP), a PIL-CN-ek szuperabszorbens jelleget mutatnak. Jól tükrözi ezt a különbséget a 18 . ábra, mely azt mutatja, hogy a kétféle kotérháló egyensúlyi duzzadásának a hányadosa az oldószerek polaritásának a függvényében egy Gauss-görbével illeszthető maximum görbét eredményez. Megjegyzendő, hogy ebben az ábrázolásban az utolsó pont a 10,2 értékü polaritással rendelkező vízhez tartozik. A PIL-CN-ek ilyen típusú különleges viselkedése többféle új alkalmazás előtt nyithatja meg az utat a gyógyászattól a környezetvédelemig.

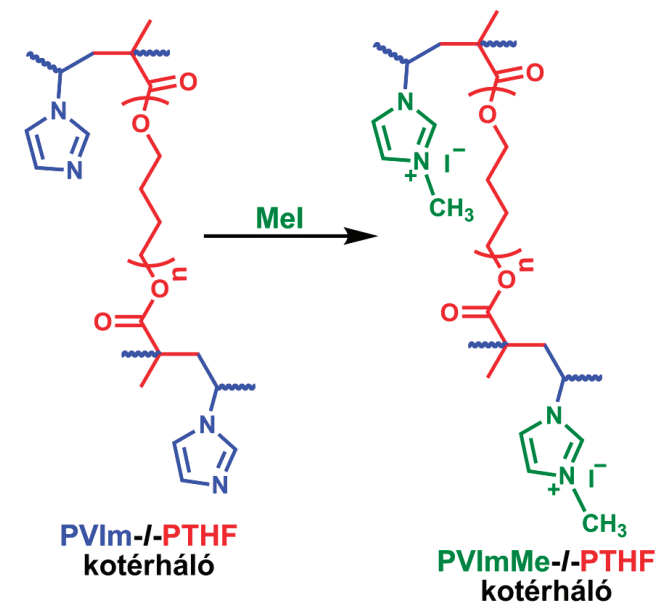

16. Ábra. Poli(ionos folyadék) kotérháló (PIL-CN) előállítása poli( $N$-vinil-imidazol)-l-poli(tetrahidrofurán) kotérháló imidazol gyürüinek metil-jodiddal történő metilezésével.

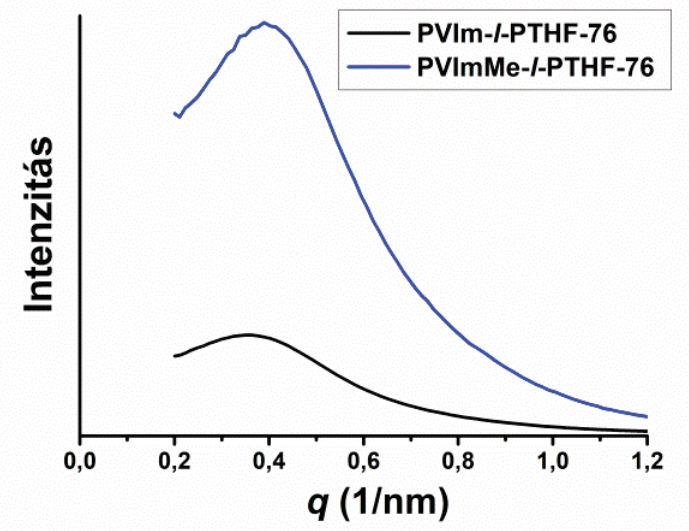

17. Ábra. A kiindulási PVIm-l-PTHF (alsó görbe) és metilezett kotérháló (PVImMe-l-PTHF, felső görbe) kisszögű röntgenszórási (SAXS) görbéi.

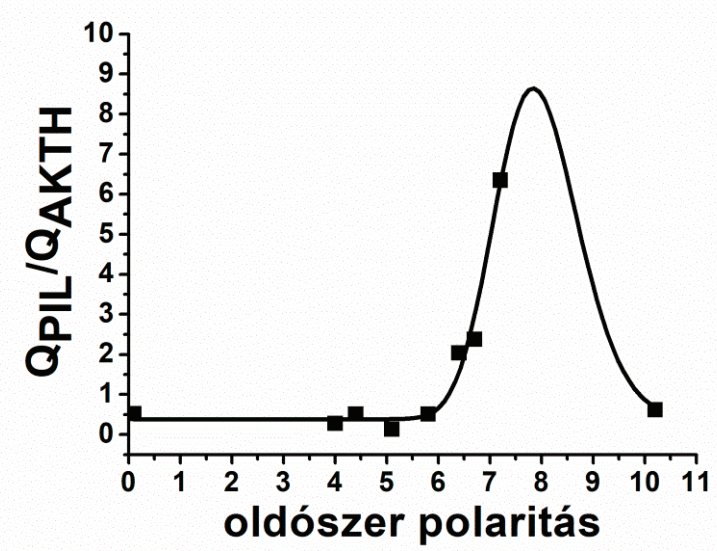

18. Ábra. Az 57 w\% PTHF-et tartalmazó PVIm-l-PTHF amfifil kotérháló (AKTH) és a metilezett származéka (PIL) egyensúlyi duzzadási fokainak a hányadosa $\left(Q_{\mathrm{PIL}} / Q_{\mathrm{AKTH}}\right)$ az oldószerek polaritásának a függvényében.

Az amfifil kotérhálók egyik legérdekesebbnek tűnő csoportjába tartoznak a polielektrolit láncokat tartalmazó kotérhálók. Különösen a poli(met)akrilsavat tartalmazó amfifil kotérhálók tünnek igen érdekes új anyagoknak. Eddigi ismereteink szerint azonban nem létezik hidrofób makromonomereknek, mint például a poliizobutilén (PIB), valamint PTHF és olyan, polielektrolitokat eredményező monomereknek és a belőlük képződő polimereknek közös oldószere, amely lehetővé tenné ilyen típusú kotérhálók közvetlen elöállítását. Sikerült azonban már korábban apoláris csoporttal, mint például trimetilsziloxi védőcsoporttal rendelkező metakrilsav (trimetoxiszilil-metakrilát) és metakrilát-telekelikus PIB kopolimerizációjával kotérhálót előállítani, és a védőcsoportot savas hidrolízissel a képződött kotérhálóban eltávolítani, amely poli(metakrilsav)-l-poliizobutilén (PMMA-l-PIB) kotérhálókat eredményezett. ${ }^{25}$ Tekintettel azonban arra, hogy a trimetoxiszilil védőcsoport könynyen hidrolizálódik már levegő nedvességének a hatására is, 1-etoxietil-védőcsoporttal rendelkező monomerekkel is megkíséreltük amfifil kotérhálók előállítását metakrilát-telekelikus PIB keresztkötővel. Ez mind metakrilsav, ${ }^{26}$ 
mind pedig akrilsav ${ }^{27}$ esetén eredményesen vezetett a kívánt poli(metakrilsav)-l-poliizobutilén (PMAA-l-PIB) és poliakrilsav-l-poliizobutilén (PAA-l-PIB) kotérhálókhoz. Mindkét polisav tartalmú kotérháló esetén azt találtuk, hogy pH-reszponzív (intelligens) duzzadási tulajdonsággal bírnak, azaz a kotérhálókban található polisavak pK értékei körül jelentősen megváltozik a duzzadási fokuk, kis pH-n kismértékü, míg a pK-nál nagyobb pH értékeknél jelentős duzzadási fokkal rendelkeznek. Azt is lényeges megfigyelésnek tartjuk, hogy míg a poli(metakrilsav) és poliakrilsav homopolimerekből álló duzzadt hidrogélek mechanikai tulajdonságai rendkívül gyengék, a PIB-bel térhálósított savas polielektrolit hidrogéleknek még nagy duzzadási fokok esetén is kiváló a mechanikai stabilitásuk, azaz a PIB keresztkötő erősitő anyag szerepét is betölti ezekben a kotérháló alapú hidrogélekben. Megvizsgáltuk, hogy a $\mathrm{pH}$ több cikluson keresztül történő változására történik-e bármilyen, a duzzadási képességet befolyásoló változás. Amint azt a 19. ábra mutatja, a PMAA-l-PIB kotérhálóknak a pH több cikluson keresztül történő változására sem változik meg jelentős mértékben a duzzadási képességük, hosszabb idejü ciklusváltásra is reverzibilis módon változik a duzzadási fokuk. Ezt a tulajdonságukat kihasználva elkészítettünk egy PMAA-l-PIB kotérhálón alapuló pH-szelepet, és demonstráltuk ennek müködőképességét is. Ez egyben azt is jelenti, hogy a poli(metakrilsav)on és poliakrilsavon alapuló kotérhálóknak a pH-változásra bekövetkező duzzadási fok változása számos további felhasználási lehetöséget kínál a gyógyászattól kezdve a legkülönfélébb, lágy anyagokkal kapcsolatos speciális és nagy hozzáadott értékü alkalmazásokig.

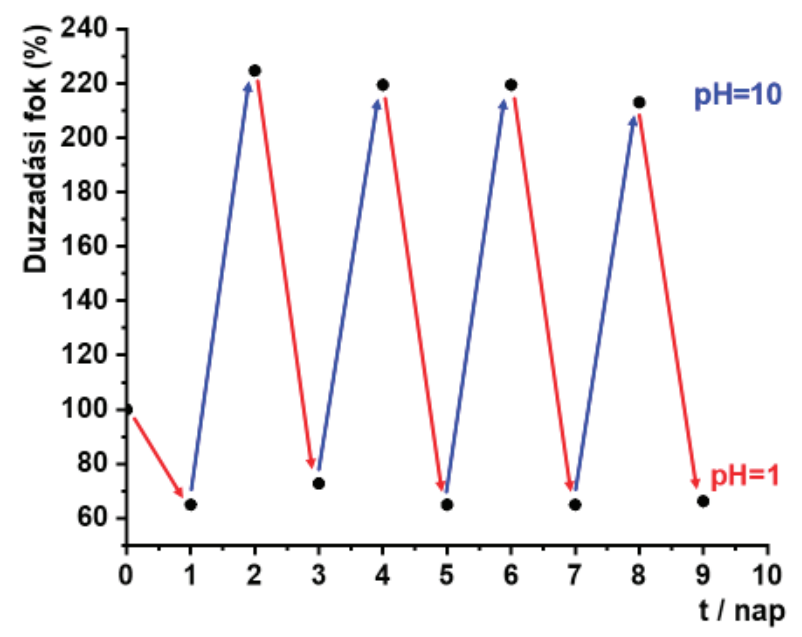

19. Ábra. Poli(metakrilsav)-l-poliizobutilén (PMAA-l-PIB) kotérhálók relatív duzzadási foka a desztillált vízben mért duzzadási fokhoz (nulla időnél 100) képest egy napos ciklusidővel $\mathrm{pH}=1$ és $\mathrm{pH}=10$ között $\left(\mathrm{M}_{\mathrm{n}, \mathrm{PIB}}=13300 \mathrm{~g} / \mathrm{mol}, \mathrm{w}_{\mathrm{PIB}}=28 \mathrm{w} \%\right)$.

Ismeretes, hogy a negatív polielektrolit hidrogélek, pl. poli(met)akrilsav és kopolimer géljeik, esetén olyan fiziológiailag fontos kétértékü kationok, mint például a kalcium ion jelenlétében, egy bizonyos ionkoncentrációnál gélkollapszus történik, amely emiatt nagy orvosbiológiai jelentőséggel bír. ${ }^{28}$ Poli(metakrilsav)-l-poliizobutilén (PMAA-l-PIB) amfifil kotérhálók (AKTH-k) duzzadási viselkedését kalcium-klorid oldatban vizsgálva azt a meglepő eredményt kaptuk, hogy viszonylag nagy PMAA tartalmú (pl. 85 w\%) AKTH-k esetében sem történik gélkollapszus jelentősebb kalcium ion koncentrációjú vizes oldatokban sem, mint azt a 20. ábra mutatja. ${ }^{29}$ Ezen az ábrán a szaggatott vonal jelzi a gélkollapszust térhálós homopolimer polielektrolit gélek esetében, és mint az jól látszik, a PMAA-l-PIB amfifil kotérhálók duzzadási foka ezzel szemben az összetételtől függő mértékben monoton csökken, és $1 \mathrm{mM}$ koncentráció körül állandóvá válik. Kimutattuk, hogy a kalcium ionokat nátrium ionokra cserélve visszaáll a kotérhálók eredeti duzzadási foka. A PMMA-l-PIB kotérhálókról tehát kiderült, hogy fiziológiailag fontos többértékủ ionok jelenlétében is stabilak maradnak, azaz nem következik be a sókoncentráció növelésével gélkollapszus, ami számos gyógyászati alkalmazásra nyújt lehetőséget.

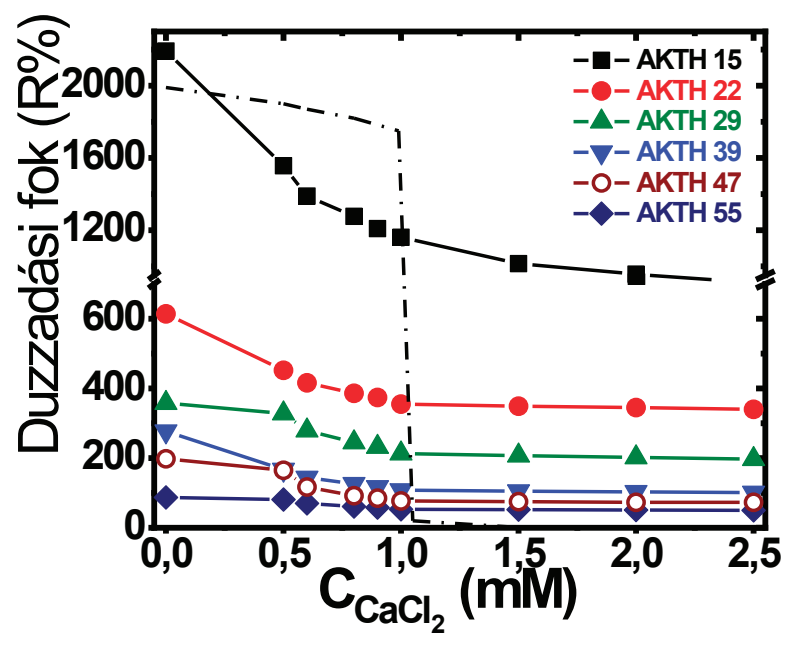

20. Ábra. Poli(metakrilsav)-l-poliizobutilén amfifil kotérhálók (AKTH-k) kalcium ion koncentrációtól függő duzzadási foka vízben (a szaggatott vonal térhálós homopolimer polieletrolit gélek gélkollapszussal járó duzzadási fokát mutatja; az AKTH-k jelölésénél a számok a PIB tartalmat jelentik w\%-ban).

Az amfifil kotérhálók széles összetétel tartományban egyedülálló kölcsönösen folytonos nanofázisú szerkezete egyedi lehetőséget kínál eddig nem létező nanohibridek létrehozására. Az egyik fázist ugyanis szelektíven duzzasztva egy prekurzor anyag oldatával, majd ebben a fázisban, mintegy nanoreaktorban, amelynek a másik, nem duzzadó fázisa képezi a nanoreaktor falát, kivitelezve egy olyan átalakítást (reakciót), amely nanoméretủ szilárd anyagot eredményez ebben a nanofázisban, nanohibridhez jutunk. Egy ilyen, nanoreaktornak alkalmas kotérháló sematikus képét mutatja a 21. ábra. Megkíséreltük ezüst és arany nanorészecskék létrehozását poli(N,N-dimetil-akrilamid)-l-poliizobutilén (PDMAAm-l-PIB) kotérhálókban oly módon, hogy ezüst-nitrát, illetve hidrogén-[tetrakloro-aurát(III)] vizes oldataival duzzasztottuk a kotérhálókat, majd a kotérhálók belsejében redukáltuk az ezüst, illetve arany ionokat, amely 
a megfelelő fém nanorészecskéket eredményezte. Mint az a 22. ábrán látható, az így kapott, arany nanorészecskéket tartalmazó kotérhálók transzmissziós elektronmikroszkópos (TEM) felvétele egyértelmúen igazolja az arany nanorészecskék létrejöttét. A kotérhálók hidrofil PDMAAm fázisában képződött arany nanorészecskék mérete a $10 \mathrm{~nm}$ körüli tartományba esik, ami megfelel a PDMAAm fázis átlagos méretének, igazolva ezzel a nanoreaktor koncepciónk müködőképességét. Hasonló eredményre jutottunk ezüst nanorészecskéket tartalmazó kotérháló alapú nanohibridek előállítása során is. Mint ismert, a nemesfémek makroszkópikus méretben a legtöbb kémiai reakció szempontjából inert anyagként viselkednek, nanoméretü részecskéik azonban jelentős kémiai aktivitást mutatnak, többek között katalitikus hatással is rendelkeznek többféle reakcióban is. Emiatt igen széles körben kutatás tárgyát képezi a fém nanorészecskék katalitikus aktivitásának a vizsgálata. Elsősorban kolloidok által stabilizált nanorészecskéket vizsgáltak eddig. Ezeknek megvan azonban az a hátránya, hogy nehezen távolíthatók el a reakcióközegből, valamint könnyen előfordulhat aggregációjuk és szedimentációjuk. Az amfifil kotérhálókon alapuló nanohibridek azonban makroszkópikus méretü, könynyen kezelhető anyagok, amelyek esetében nem lépnek fel a kolloidok által stabilizált nanorészecskéknél tapasztalható problémák. Ezzel kapcsolatban meg kell jegyezzük, hogy a stabilizáló anyagok, többek között polimerek, szerkezetének előnyös megválasztásával elérhető a szervetlen nanorészecskék nagyfokú stabilitása. Erre mutatnak egyedülálló példát a Szegedi Egyetem munkatársaival folytatott együttműködésünk során kváziélő atomátadásos gyökös polimerizációval (ATRP = Atom Transfer Radical Polymerization) elöállított poli(poli(etilén-glikol)-metakrilát-ko-akrilsav) kopolimerekkel kapott eredmények, melyek szerint ezek a kopolimerek szuperparamágneses vas-oxid nanorészecskék nagyfokú és hosszútávú stabilitását eredményezték, amelyek így biológiai alkalmazást nyerhetnek, például mint MRI kontrasztanyagok. ${ }^{30-32}$ Mint azt példaként a 23. és 24. ábrák mutatják, ezüst nanorészecskéket tartalmazó PDMAAm-l-PIB kotérhálók nagy aktivitású katalizátornak bizonyultak a környezetileg káros 4-nitrofenol nátrium-borohidriddel 4-aminofenollá történő redukciójában. Jól látható ezeken az ábrákon, hogy a 4-nitrofenol abszorbanciája fél óra alatt közel nullává csökken, azaz teljessé válik ez a redukciós reakció a kotérháló-ezüst nanohibrid katalitikus hatása következtében. Meg kell említeni, hogy katalizátor hiányában nem következik be ez a redukció hosszabb idő elteltével sem. Ezek az újfajta nanohibridek tehát számos lehetőséget kínálnak akár a környezetszennyezés csökkentésére, akár különféle reakciók hatékony katalizátoraként vagy egyéb speciális, például fotonikai, elektronikai stb. alkalmazásokra.

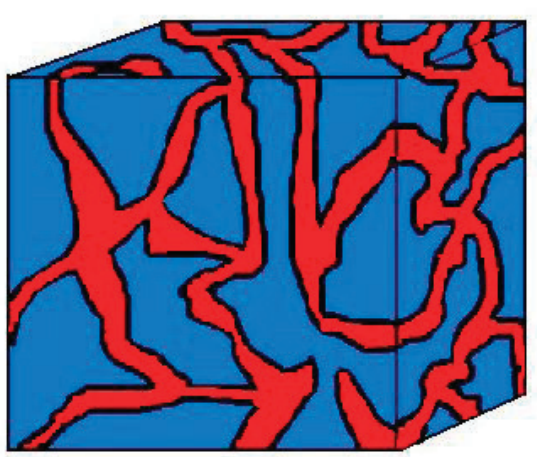

21. Ábra. Nanoreaktornak alkalmas, kölcsönösen folytonos nanofázis szerkezetű kotérháló sematikus képe.
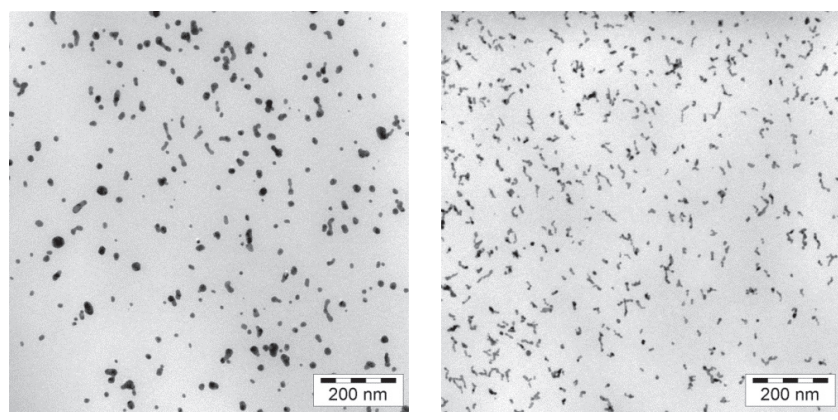

22. Ábra. Hidrazinnal (bal oldali kép) és $\mathrm{NaBH}_{4}$ oldattal (jobb oldali kép) történő redukálás eredményeként kapott, arany nanorészecske tartalmú poli(N,N-dimetil-akrilamid)-l-poliizobutilén (PDMAAm-l-PIB) kotérhálók transzmissziós elektronmikroszkópos (TEM) felvételei $\left(\mathrm{M}_{\mathrm{n}, \mathrm{PIB}}=6230 \mathrm{~g} / \mathrm{mol}, \mathrm{w}_{\mathrm{PIB}}=31 \mathrm{w} \%\right)$.

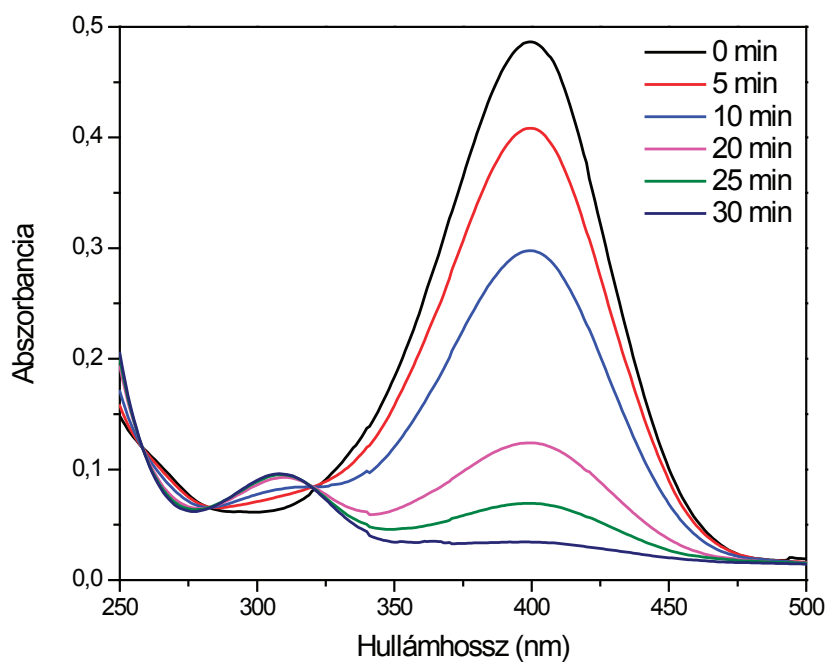

23. Ábra. A 4-nitrofenol és nátrium-borohidrid reakcióelegy UV-VIS spektruma a reakcióidő függvényében PDMAAm-l-PIB-ezüst nanohibrid katalizátor jelenlétében $\left(\mathrm{w}_{\mathrm{PIB}}=50 \mathrm{w} \%\right.$ a kotérhálóban, 4-nitrofenol: $\left.\mathrm{NaBH}_{4}=1: 200\right)$. 


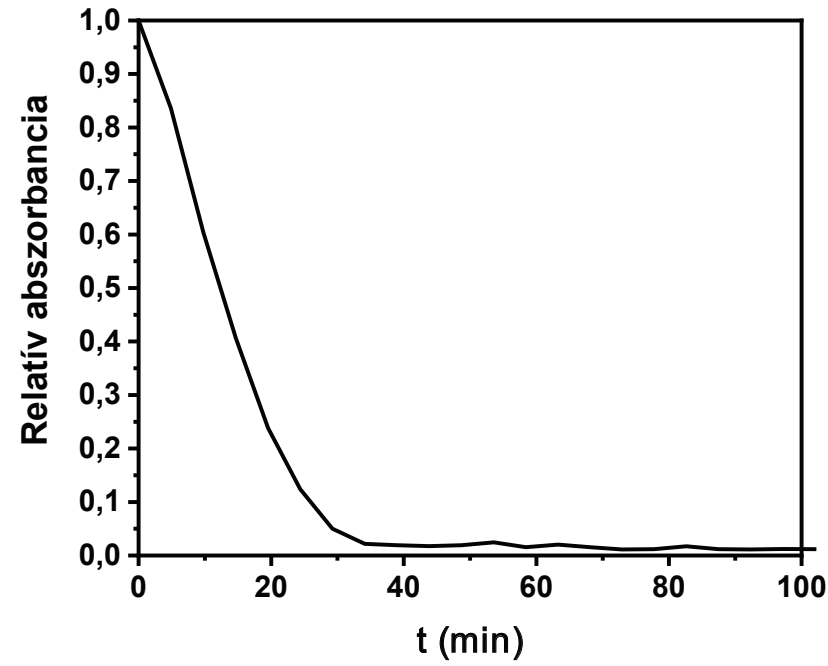

24. Ábra. A 4-nitrofenol és nátrium-borohidrid reakcióelegy 400 nm-nél mért relatív abszorbanciája a reakcióidő függvényében PDMAAm-lPIB-ezüst nanohibrid katalizátor jelenlétében $\left(\mathrm{w}_{\mathrm{PIB}}=50 \mathrm{w} \%\right.$ a kotérhálóban, 4-nitrofenol: $\left.\mathrm{NaBH}_{4}=1: 200\right)$.

\section{4. Összefoglalás}

Az utóbbi években kopolimerekkel és polimer kotérhálókkal folytatott kutatásaink föbb eredményeit foglalja össze ez a tanulmány. Ennek során sikeresen valósítottuk meg N-izopropil-akrilamid (NIPAAm) és 3-trimetoxiszililpropil-metakrilát (TMSPMA) gélesedés nélküli kopolimerizációját, amely szol-gél kémiai reakcióra alkalmas termoreszponzív (intelligens) kopolimereket eredményezett. Ezek termoreszponzív viselkedésének tanulmányozása során egy új, eddig nem ismert jelenséget tapasztaltunk, miszerint a szol-gél reakció a kopolimerek kritikus oldhatósági hőmérséklete fölötti hőmérsékleten katalizátor hozzáadása nélkül lejátszódik, és oldhatatlan térhálós polimerek képződnek.

Sikeresen állítottunk elö mindössze egy amin-csoportot tartalmazó monofunkciós hiperelágazásos poliglicerolt (HbPG) glicidol ftálimid/kálium-ftálimid iniciátor rendszerrel kivitelezett anionos gyürűfelnyílásos multielágazásos polimerizációjával és azt követő hidrazinos kezeléssel, amellyel végzett vizsgálataink eredményei szerint kiemelkedő sajátságú, célzott tumorterápiára alkalmas bikonjugátumok előállítása válik lehetővé. HbPGpoli(tetrahidrofurán)-HbPG (HbPG-PTHF-HbPG) szintézise amin-telekelikus PTHF-fel olyan ABA blokk-kopolimereket eredményezett, melyek vízben rosszul oldódó hatóanyagok, például kurkumin, rendkívül hatékony szolubilizáló hordozójának bizonyultak. Azt találtuk, hogy AB típusú HbPG alapú blokk-kopolimerek pedig kiváló stabilizáló hatással rendelkeznek vízben nem diszpergálható biodegradábilis polimer, például poli( $\varepsilon$-kaprolakton) és poli(tejsav-ko-glikolsav), nanorészecskék esetében.

Kutatócsoportunk alapvetően új eredményeket ért el az elmúlt években egymással nem elegyedő, kovalens kémiai kö- tésekkel összekapcsolt polimer láncokból felépülő polimer kotérhálók kutatása terén. Kimutattuk, hogy az üvegesedési átmenet szempontjából az úgynevezett, korábban csak egy esetben közölt "olló effektus" más felépítésü kotérhálók esetén is érvényes, ami arra utalhat, hogy ez egy általános jelenség a polimer kotérhálók körében. Szisztematikus atomerő mikroszkópos (AFM) vizsgálatokkal felderítettük poli(N-vinil-imidazol)-l-poli(tetrahidrofurán) (PVIm-lPTHF) amfifil kotérhálók (AKTH-k) nanofázisszeparált szerkezetét, melynek során azt találtuk, hogy ezek a kotérhálók széles összetétel tartományban kölcsönösen folytonos (kofolytonos), 5-15 nm méretü doménekből álló nanofázisú morfológiával rendelkeznek. Tudomásunk szerint a világon elsőként állítottunk elő PVIm-l-PTHF amfifil kotérhálók alkilezésével poli(ionos folyadék) (PIL) kotérhálókat. AFM és kisszögü röntgenszórás (SAXS) mérésekkel ezekröl kiderült, hogy megtartják a kiindulási kotérhálókhoz hasonló nanofázisú szerkezetüket és szuperabszobensként viselkednek bizonyos oldószerek (DMSO, DMF, NMP) esetében. Furcsa, eddig nem ismert módon az oldószer polaritás függvényében a PIL kotérhálók relatív egyensúlyi duzzadási fokai jól illeszthetők egy Gauss-görbével. Trimetilszililoxi és 1-etoxietil védőcsoportok alkalmazásával sikeresen állítottunk elő $\mathrm{pH}$-reszponzív poli(metakrilsav)- $l$-poliizobutilén (PMAA- $l$-PIB) és poliakrilsav- $l$-poliizobutilén polielektrolit kotérhálókat. A pH-reszponzív tulajdonságuk alapján létrehoztunk egy $\mathrm{pH}$-szelep prototípusát. A PMAA-l-PIB hidrogéljeivel kapcsolatban olyan eredményeket kaptunk, miszerint szemben a homopolimer polielektrolit gélekkel, a polielektrolit kotérhálók esetén nem következik be még viszonylag nagy kalcium ion koncentrációknál sem gélkollapszus, ami lehetőséget biztosít széleskörü orvosbiológiai felhasználásukra. A nanofázisú kotérhálókról igazoltuk, hogy szelektív duzzasztással nanoreaktorként müködnek, és a kiválasztott fázisban lezajló reakciókkal eddig nem ismert, újszerü, speciális nanohibridek hozhatók létre. Sikeresen elöállítottunk kotérháló-ezüst és kotérháló-arany nanohibrideket. Azt találtuk, hogy a kotérháló-ezüst nanohibridek kiváló, többször felhasználható katalizátorai a környezetileg káros nitrofenol redukciójának. Együttmüködésben a Szegedi Egyetem munkatársaival azt találtuk, hogy kváziélő atomátadásos gyökös polimerizációval (ATRP) előállított poli(poli(etilén-glikol)-metakrilát-ko-akrilsav) kopolimerek hatékony stabilizátorai szuperparamágneses vas-oxid nanorészecskéknek, amely lehetőséget teremthet ezek MRI kontrasztanyagként történő felhasználására.

Összegzésül megállapíthatjuk, hogy a kutatócsoportunkban az elmúlt időszakban előállított új makromolekuláris anyagok és az elért új eredmények előrevetítik ezeknek az új anyagoknak a széles felhasználási lehetőségeit a gyógyászattól az energetikáig és környezetvédelemig. 


\section{Köszönetnyilvánítás}

Hálás köszönettel tartozom a kutatócsoportunk munkájában résztvevő minden eddigi és jelenlegi munkatársamnak, hallgatóknak és diákoknak. Külön köszönöm a közös munkát és közös erőfeszítéseinket azoknak, akikkel együtt dolgozhattam az elmúlt fél évtizedben: Aiman Aitkazina, Aldilene Santos Franca, Alexin Balázs, Alexy Andrea, Bajcsi Áron, Becsei Bálint, Bencskó György, Bisztrán Márk, Domján Attila, Erdős Mátyás, Érsek Gábor, Fecske Dóra, Fejér Máté, Fodor Csaba, György Csilla, Ignáth Tamás, Kali Gergely, Kalocsai Dániel, Kasza György, Koronka Dániel, Kovács Ervin, Lontay Dávid, Menyhért Balázs, Mészáros Márton, Mohácsi Attila, Néder Anita, Nádor Attila, Osváth Zsófia, Pásztói Balázs, Pásztor Szabolcs, Petróczy Anna, Podlaviczki Blanka, Réti Zsombor, Sármezey Bence, Sasvári Gergő, Sóvári Beatrix, Stumphauser Tímea, Szabari Zalán, Szabó Ákos, Szanka István, Szarka Györgyi, Szőke Anita, Tóth Tamás, Varga Bence, Verebélyi Klára, Závoczki László, Zvekán Fanni. Köszönöm munkahelyem (MTA TTK, TTK) minden munkatársának és vezetőinek, hogy munkánkat segítették, támogatták, közülük különösen a következőknek: Buday László, Keserü György Miklós, Pokol György, Szépvölgyi János, Tompos András. Együttmüködő hazai és külföldi partnereinknek, közülük is különösen a következőknek ezúton is köszönöm az eredményes közös munkát: Ábrahám Ágnes, Bánhegyi Péter, Bocz Katalin, Dmitrij Bondarev, Bősze Szilvia, Csiszár Emília, Gyulai Gergő, Hajós Szilárd, Hegedüs Imre, Horváti Kata, Illés Erzsébet, Inzelt György, Karger-Kocsis József, Kállay-Menyhárd Alfréd, Karsai Péter, Kerényi Péter, Benjamin Kerscher, Kéki Sándor, Kiss Éva, Kőhidai László, Kun Róbert, Lajkó Eszter, Láng Orsolya, Madarász János, Marosi György, Marossy Kálmán, Medzihradszky-Schweiger Hedvig, Mihály Judith, Mező Gábor, Molnár Andor, Molnár Péter, Jaroslav Mosnacek, Katarina Mosnácková, Németh Péter, Rolf Mülhaupt, Nagy Endre, Nagy Gábor, Nagy Nóra, Neurórh Katalin, Pethő Lilla, Pomlényi Péter, Pomozi István, Ronkay Ferenc, Semperger Orsolya, Szabó Ilona, Szabó Márk, Száz Dénes, Szebényi Gábor, Tamás-Bényei Péter, Ralf Thomann, Yi Thomann, Tombácz Etelka, Tóth Ildikó, Tobias Tröschler, Vargha Viktória, Varga Zoltán, Wacha András, Zsuga Miklós. Köszönöm a kutatásaink anyagi támogatását a következő intézményeknek és programoknak: Nemzeti Kutatási és Technológiai Hivatal (NKTH) (K81592，K112094， NN116252， NN129366), BIONANO_GINOP-2.3.2-15-2016-00017 program, Európai Unió Regionális Program (EU-HUSK), European Research Area Chemistry (ERA-Chemistry) program, Deutsche Forschungsgemeinschaft (DFG), HunProtEx program, MedInProt program.

\section{Irodalomjegyzék}

1. Staudinger, H. Berichte Der Deutschen Chemischen Gesellschaft (A and B Series) 1920, 53, 1073-1085. https://doi.org/10.1002/cber.19200530627

2. Mülhaupt, R. Angew. Chem., Int. Ed. 2004, 43, 1054-1063. https://doi.org/10.1002/anie.200330070

3. Carothers, W. H. J. Am. Chem. Soc. 1929, 51, 2548-2559. https://doi.org/10.1021/ja01383a041

4. Iván, B. Magyar Tudomány 2010, 171, 280-287

5. Stone Age, Iron Age, Polymer Age, in "Opportunities in Chemistry", szerk.: Pimentel, G., National Academy of Sciences of the USA, Washington, D. C., 1985, pp. 47-60. ISBN 978-0-309-03633-7

6. Iván, B. Magyar Kémiai Folyóirat 2016, 122, 5-12.

7. Osváth, Zs.; Iván, B. Macromol. Chem. Phys. 2017, 218, 1600470. https://doi.org/10.1002/marc.201600724

8. Osváth, Zs.; Tóth, T.; Iván, B. Polymer 2017, 108, 395-399. https://doi.org/10.1016/j.polymer.2016.12.002

9. Osváth, Zs.; Tóth, T.; Iván, B. Macromol. Rapid Copmmun 2017, 38, 1600724. https://doi.org/10.1002/marc.201600724

10. Kasza, Gy.; Fecske, D.; Gyulai, G.; Horváti, K; Szabó, M.; Szarka, Gy.; Kiss, É.; Domján, A.; Bősze, Sz.; Iván, B. közlés alatt

11. Lim, S.-H.; Cha, E.-J.; Huh, J.; Ahn, C.-H. Macromol. Chem. Phys., 2009, 210, 1734-1738. https://doi.org/10.1002/macp.200900217

12. Kasza, Gy.; Gyulai, G.; Ábrahám, Á.; Szarka, Gy.; Iván, B.; Kiss, É. RSC Adv. 2017, 7, 4348-4352. https://doi.org/10.1039/C6RA27843D

13. Nagy, N. Zs.; Varga, Z.; Mihály, J.; Kasza, Gy.; Iván, B.; Kiss, É. eXPRESS Polym. Lett. 2020, 14, 90-10. https://doi.org/10.3144/expresspolymlett.2020.8

14. Kasza, Gy.; Kali, G.; Domján, A.; Pethő, L.; Szarka, Gy.; Iván, B. Macromolecules, 2017, 50, 3078-3088. https://doi.org/10.1021/acs.macromol.7b00413

15. Pethő, L.; Kasza, Gy.; Lajkó, E.; Lang, O.; Kőhidai, L.; Iván, B.; Mező, G. Soft Matter 2020, 16, 5759-5769. https://doi.org/10.1039/D0SM00428F

16. Amphiphilic Polymer Co-networks: Synthesis, Properties, Modelling and Applications, Ed., Patrickios, C. S., The Royal Society of Chemistry, Cambridge, 2020 ISBN 978-1-78801-370-3

17. Fodor, Cs.; Stumphauser, T.; Iván, B. "Poly(N-vinylimidazole)-Based Nanostructured Amphiphilic Conetworks", in "Amphiphilic Polymer Co-networks: Synthesis, Properties, Modelling and Applications", Ed., Patrickios, C. S.; The Royal Society of Chemistry, Cambridge, 2020, pp. 15-46. https://doi.org/10.1039/9781788015769-00015

18. Fodor, Cs.; Kali, G.; Iván, B. Macromolecules 2011, 44, 4496-4502.

https://doi.org/10.1021/ma200700m

19. Fodor, Cs.; Kali, G.; Thomann, R.; Thomann, Y.; Iván, B.; Mülhaupt, R. RSC Adv. 2017, 7, 6827-6834. https://doi.org/10.1039/C6RA25356C

20. Stumphauser, T.; Kasza, G.; Domján, A.; Wacha, A.; Varga, Z.; Thomann, Y.; Thomann, R.; Pásztói, B.; Trötschler, T. M.; Kerscher, B.; Mülhaupt, R.; Iván, B. Polymers 2020, 12, 2292. https://doi.org/10.3390/polym12102292

21. Iván, B.; Haraszti, M.; Erdődi, G.; Scherble, J.; Thomann, R.; Mülhaupt, R. Macromol. Symp. 2005, 227, 265-273 https://doi.org/10.1002/masy.200550926

22. Fodor, Cs.; Domján, A.; Iván, B. Polym. Chem. 2013, 4, 3714-3724.

https://doi.org/10.1039/c3py00299c 
23. Pásztor, Sz.; Becsei, B.; Szarka, Gy.; Thomann, Y.; Thomann, R.; Mühlhaupt, R.; Iván, B. Materials 2020, 13, 4822. https://doi.org/10.3390/ma13214822

24. O’Driscoll, K.; Saneyei, R. A. Macromolecules 1991, 24, 4779-4780. https://doi.org/10.1021/ma00015a038

25. Haraszti, M.; Tóth, E.; Iván, B. Chem. Mater. 2006, 18, 4952-4958. https://doi.org/10.1021/cm061119v

26. Kali, G.; Iván, B. Macromol. Chem. Phys. 2015, 216, 605-613. https://doi.org/10.1002/macp.201400478

27. Pásztor, Sz.; Iván, B.; Kali, G. J. Polym. Sci., Part A: Polym. Chem. 2017, 55, 1818-1821. https://doi.org/10.1002/pola.28569
28. Horkay, F.; Tasaki, I.; Basser, P. J. Biomacromolecules 2001, 2, 195-199. https://doi.org/10.1021/bm0056153

29. Kali, G.; Iván, B. Eur. Polym. J. 2016, 84, 668-674. https://doi.org/10.1016/j.eurpolymj.2016.10.006

30. Illés, E.; Tombácz, E.; Szekeres, M.; Tóth, I. Y.; Szabó, Á.; Iván, B. J. Magn. Magn. Mater. 2015, 380, 132-139. https://doi.org/10.1016/j.jmmm.2014.10.146

31. Illés, E.; Szekeres, M.; Tóth, I. Y.; Farkas, K.; Földesi, I.; Szabó, Á.; Iván, B.; Tombácz, E. Nanomaterials 2018, 8, 776. https://doi.org/10.3390/nano8100776

32. Illés, E.; Szekeres, M.; Tóth, I. Y.; Szabó, Á.; Iván, B.; Turcu, R.; Vékás, L.; Zupkó, I.; Jaics, E.; Tombácz, E. J. Magn. Magn. Mater. 2018, 451, 710-720. https://doi.org/10.1016/j.jmmm.2017.11.122

\section{Polymer conetworks and copolymers: from chameleon gels to intelligent drug carriers and nanocatalysts}

This study summarizes our research achievements obtained in the course of recent years. The gel-free copolymerization of $\mathrm{N}$-isopropylacrylamide (NIPAAm) and 3-trimethoxysilylpropyl methacrylate (TMSPMA) was successfully accomplished, which resulted in thermoresponsive (intelligent) copolymers capable of sol-gel reaction for obtaining various novel polymer structures. The investigation of the thermoresponsive behavior of the NIPAAm-TMSPMA copolymers resulted in the observation of a phenomenon not known previously, according to which the sol-gel reaction takes place without the addition of any catalyst above the critical solution temperature of the copolymers resulting in insoluble crosslinked polymers.

Hyperbranched polyglycerol (HbPG) with one amine functionality was successfully synthesized by the anionic ring-opening multibranching polymerization of glycidol with the phthalimide/potassium-phthalimide initiating system followed by treatment with hydrazine monohydrate. Our investigations showed that the monoamine functional $\mathrm{HbPG}$ is an excellent conjugating agent for peptide bioconjugates with receptor targeting moieties connected to antitumor agents. The synthesis of HbPGpoly(tetrahydrofuran)-HbPG (HbPG-PTHF-HbPG) ABA block copolymers with amine-telechelic PTHF macroinitiators resulted in nanomicelles in aqueous media, which proved to be outstanding solubilizing materials for water insoluble compounds and drugs, such as curcumin. It has been found by us that AB-type amphiphilic block copolymers of HbPG are excellent stabilizing agents for nanoparticles of water-insoluble nanoparticles of biocompatible polymers, such as poly( $\varepsilon$-caprolactone) and poly(lactic/glycolic acid).

Our research group has achieved several fundamentally new research results in the course of the investigations of polymer conetworks composed of covalently bonded, otherwise immiscible polymer chains. It has been found that the socalled "scissor effect" related to the glass transition temperature of the crosslinked chains in conetworks, reported for one conetwork type previously, is valid in another conetwork series as well. This indicates that this phenomenon is most likely a general property of polymer conetworks. With systematic atomic force microscopy (AFM) investigations on poly(N-vinylimidazole)-l-poly(tetrahydrofuran) (PVIm-l-PTHF) conetworks, it has been revealed that the immiscible polymer components form nanophases with $5-15 \mathrm{~nm}$ domain sizes, and bicontinuous (cocontinuous) nanophasic morphology exists in broad composition ranges in these conetworks.
To the best of our knowledge, poly(ionic liquid) (PIL) conetworks were obtained by us first time by the alkylation of the imidazole moieties in the PVIm-l-PTHF conetworks. The results of AFM and small angle X-ray (SAXS) measurements revealed that the PIL conetworks keep the bicontinuous nanophasic morphologies even after the alkylation process. It was found that the new PIL conetworks behave as superabsorbents for aprotic polar solvents, such as DMSO, DMF and NMP. Surprisingly, a so far unkown Gaussian type relationship was observed between the relative equilibrium swelling ratios of the PIL conetworks as a function of solvent polarity.

With the use of trimethylsilyloxy and 1-ethoxyethyl protecting groups, a series of $\mathrm{pH}$-responsive poly(methacrylic acid)-l-polyisobutylene (PMAA-l-PIB) and poly(acrylic acid)- $l$-polyisobutylene polyelectrolyte conetworks were successfully synthesized. On the basis of the pH-responsive behavior of the PMAA-l-PIB conetworks, a pH-valve prototype was successfully assembled and tested. It was found by us that in contrast to homopolymer polyelectrolyte hydrogels, the PMAA-l-PIB conetworks do not undergo gel collapse even at relatively high calcium ion concentrations, which provides broad medical application possibilities for these conetworks and their hydrogels. The nanophasic bicontinuous morphology of amphiphilic conetworks were utilized as nanoreactor for the synthesis of specialty nanohybrids by selectively swelling one of the nanophases with reactants and carrying out the reaction inside the swollen nanophase to form nanoparticles. This way, conetwork-silver and conetwork-gold nanohybrids were successfully prepared. It was found that the conetwork-silver nanohybrids are highly efficient, easily recyclable catalysts for the reduction of the environmentally dangerous 4-nitrophenol. As to inorganic nanoparticles, in collaboration with colleagues at the University of Szeged, it was proved that superparamagnetic iron oxide nanoparticles are efficiently stabilized by poly(poly(ethylene glycol) methyacrylate-co-acrylic acid) random copolymers prepared by quasiliving atom transfer radical polymerization (ATRP). This provides a unique opportunity to apply such effectively stabilized iron oxide nanoparticle dispersions as MRI contrasting agents.

In sum, it can be concluded that the new macromolecular materials developed and the new scientific results obtained in the course of the research activities in our group can be broadly utilized in fields like medical applications, energetics and environmental protection. 